\title{
A new method for the characterisation and quantitative speciation of base metal smelter stack particulates
}

\author{
James M. Skeaff • Yves Thibault • \\ David J. Hardy
}

Received: 22 October 2009 / Accepted: 9 July 2010 / Published online: 30 July 2010

(C) The Author(s) 2010. This article is published with open access at Springerlink.com

\begin{abstract}
Base metal smelters may be a source of particulates containing metals of environmental concern released to the atmosphere. Knowledge of the quantitative chemical speciation of particulate releases from base metal smelters will be of value in smelter emission fingerprinting, sitespecific risk assessments, predictions of the behaviour of smelter stack particulates released to the environment and in resolving liability issues related to current and historic releases. Accordingly, we have developed an innovative approach comprising bulk chemical analysis, a leaching procedure, X-ray diffraction analysis and scanning electron microscopy/electron probe microanalysis characterisation in a step-wise apportioning procedure to derive the quantitative speciation of particulate samples from the stacks of three copper smelters designated as A, B and C. For the A smelter stack particulates, the major calculated
\end{abstract}

J. M. Skeaff $(\varangle) \cdot$ Y. Thibault · D. J. Hardy

CANMET Mining and Mineral Sciences Laboratories, 555 Booth Street, Ottawa, K1A 0G1, Canada e-mail: jskeaff@nrcan.gc.ca

Y. Thibault

e-mail: ythibaul@nrcan.gc.ca

D. J. Hardy

e-mail: dhardy@nrcan.gc.ca percentages were $29 \mathrm{CuSO}_{4}, 20 \mathrm{ZnSO}_{4} \cdot \mathrm{H}_{2} \mathrm{O}$, $13\left(\mathrm{Cu}_{0.94} \mathrm{Zn}_{0.06}\right)_{2}\left(\mathrm{AsO}_{4}\right)(\mathrm{OH}), 11 \mathrm{PbSO}_{4}$ and four $\mathrm{As}_{2} \mathrm{O}_{3}$. For the $\mathrm{B}$ smelter stack particulates, the primary calculated percentages were $20 \mathrm{ZnSO}_{4} \cdot \mathrm{H}_{2} \mathrm{O}, 20 \mathrm{PbSO}_{4}, 12 \mathrm{CuSO}_{4}$ and nine $\mathrm{As}_{2} \mathrm{O}_{3}$. Finally, we calculated that the $\mathrm{C}$ smelter stack particulates mostly comprised $34 \mathrm{ZnSO}_{4} \cdot \mathrm{H}_{2} \mathrm{O}, 19\left(\mathrm{Cu}_{0.84} \mathrm{Zn}_{0.16}\right)\left(\mathrm{AsO}_{3} \mathrm{OH}\right), 11$ $\mathrm{PbSO}_{4}, 10 \mathrm{As}_{2} \mathrm{O}_{3}$ and nine $\mathrm{Zn}_{3}\left(\mathrm{AsO}_{4}\right)_{2}$. Between $56 \%$ and $67 \%$ by weight of the smelter stack particulates, including the As, was soluble in water. For these and other operations, the data and approach may be useful in estimating metals partitioning among water, soil and sediment, as well as predictions of the effects of the stack particulates released to the environment.

Keywords Base metal smelters •

Stack particulates $\cdot$ Metal speciation - Arsenic • Arsenates $\cdot$ Copper $\cdot$ Lead $\cdot$ Zinc

\section{Introduction}

Smelting, converting and fire-refining of base metal concentrates can generate considerable volumes of gases which are usually passed through electrostatic precipitators to remove almost all of the entrained particulates. However, some particulates are inevitably released to the atmosphere. 
Particulates may be formed during smelting and other pyrometallurgical operations chemically, by the vaporisation of solid or liquid chemicals followed by condensation, and mechanically, by physical breakdown of compounds into smaller particles (Samuelsson and Carlsson 2001).

Some base metal particulates can contain substances of environmental concern. For instance, Doyle et al. (2003) noted that aquatic and soil organisms close to copper and zinc smelters may incur adverse effects. In Canada, base metal smelters are required to prepare and implement comprehensive Pollution Prevention Plans and to publicly report on their conformance with an Environmental Code of Practice for Base Metals Smelters and Refineries (Environment Canada 2006). The requirement covers inorganic compounds of arsenic, cadmium, lead, mercury, certain compounds of nickel and particulate matter containing metals released from copper smelters and zinc plants (Canada Gazette 2006).

Moreover, Canada and 28 other countries have ratified the United Nations Economic Commission for Europe (UNECE) Convention on LongRange Transboundary Air Pollution Protocol on Heavy Metals (UNECE 1998). The parties to the Convention are obligated to reduce their emissions of $\mathrm{Cd}, \mathrm{Hg}$ and $\mathrm{Pb}$ from industrial sources (the non-ferrous metals and the iron and steel industries), combustion processes (power generation and road transport) and waste incineration to below their 1990 levels.

A typical copper smelter treats sulphide concentrates at elevated temperatures to produce a copper metal suitable for electro-refining (Biswas and Davenport 1994). In addition to $\mathrm{Cu}, \mathrm{Fe}$ and $\mathrm{S}$ in the minerals chalcopyrite $\left(\mathrm{CuFeS}_{2}\right)$, chalcocite $\left(\mathrm{Cu}_{2} \mathrm{~S}\right)$, covellite $(\mathrm{CuS})$, bornite $\left(\mathrm{Cu}_{5} \mathrm{FeS}_{4}\right)$, the concentrates typically contain minor and trace quantities of $\mathrm{Ag}, \mathrm{As}, \mathrm{Au}, \mathrm{Cd}, \mathrm{Co}, \mathrm{Ni}$, $\mathrm{Pb}, \mathrm{Sb}$, Se and $\mathrm{Zn}$ residing in distinct phases or in solid solution in the copper-bearing matrices. Copper concentrates usually also contain various silicate minerals such as chlorite $\left((\mathrm{Mg}, \mathrm{Fe})_{3}(\mathrm{Si}, \mathrm{Al})_{4} \mathrm{O}_{10}(\mathrm{OH})_{2} \cdot(\mathrm{Mg}, \mathrm{Fe})_{3}(\mathrm{OH})_{6}\right)$ and at least some from the feldspar group such as orthoclase $\left.(\mathrm{K}) \mathrm{AlSi}_{3} \mathrm{O}_{8}\right)$, microcline $\left(\mathrm{KAlSi}_{3} \mathrm{O}_{8}\right)$ and anorthoclase $\left((\mathrm{Na}, \mathrm{K}) \mathrm{AlSi}_{3} \mathrm{O}_{8}\right)$ (Dana and Ford 1958).
The copper concentrates are usually smelted at about $1200^{\circ} \mathrm{C}$ with fluxing materials such as $\mathrm{CaO}$ and $\mathrm{SiO}_{2}$ to separate a liquid $\mathrm{Cu}-\mathrm{Fe}-\mathrm{S}$ phase known as a matte, with the viscosity of water, from a liquid oxide slag phase, with the viscosity of molasses that overlies the matte. The matte and slag phases are separated by gravity, with the slag being discarded and the matte proceeding to a conversion stage. In the converter, tonnage oxygen is blown into the matte with more fluxing materials to convert the $\mathrm{S}$ to $\mathrm{SO}_{2}$, transfer the $\mathrm{Fe}$ to the converter slag with some of the $\mathrm{Cu}$ and many of the minor and trace elements, and yield an impure $\mathrm{Cu}$ liquid known as blister copper containing $0.03 \%$ or less $\mathrm{S}$ and $1 \%$ or less dissolved oxygen. In continuous converting processes, the $\mathrm{SO}_{2}$ is also converted to sulphuric acid. The blister copper is fire-refined with either natural gas, ammonia or wood to remove the dissolved oxygen, and is then cast into anodes for electro-refining.

Some smelter emission characterisation studies have been reported in the literature. For instance, Samuelsson and Björkman (1998) applied bulk chemical analysis, X-ray diffraction (XRD) analysis and electron probe $\mathrm{X}$-ray microanalysis (EPMA) to examine samples of particles from various stages in the converter gas stream of a copper smelter. Using XRD, they identified $\mathrm{SiO}_{2}$, $\mathrm{CuFeS}_{2}, \mathrm{Cu}_{2-y} \mathrm{~S}, \mathrm{Cu}_{5} \mathrm{FeS}_{4}, \mathrm{PbSO}_{4}, \mathrm{CuO} . \mathrm{CuSO}_{4}$ and $\mathrm{FeS}_{2}$ in the samples. The variability in metal content could be quite substantial and depended on the sampling location. For instance, $\mathrm{Cu}$ in the particulates could vary between $0.2 \%$ and $66 \%$, and the values for As between $0.25 \%$ and $12 \%$. Since they reported their bulk chemical analyses in terms of the percentages of the elements $\mathrm{Fe}, \mathrm{Cu}$, $\mathrm{Cd}, \mathrm{Pb}, \mathrm{As}, \mathrm{Sn}, \mathrm{Sb}, \mathrm{Bi}$ and $\mathrm{S}$, the total percentages were less than $100 \%$, and the speciation of the elements is unknown.

Using XRD and EPMA, Samuelsson and Carlsson (2001) examined the dusts from four locations in a copper smelting plant. They reported weight percentages of the elements $\mathrm{Cu}(2-20 \%)$, Fe (1-30\%), Zn (6-33\%), Pb (3-20\%), Sb (0.05$1 \%)$, As (1-12\%), S (2-12\%), Sn (<0.01-2\%) and $\mathrm{SO}_{4}(4-23 \%)$, although in totals of less than $100 \%$ which might have been attained had they been able to assign speciation to the elements. From their microprobe analysis, they detected such 
species as $\mathrm{CuFeS}_{2}, \mathrm{Cu}_{5} \mathrm{FeS}_{4}, \mathrm{~K}$-feldspar, $\mathrm{SiO}_{2}, \mathrm{Fe}-$ $\mathrm{Cu}$ oxide and small particles containing $\mathrm{Zn}$, As, $\mathrm{Pb}, \mathrm{Cu}, \mathrm{Fe}, \mathrm{Si}, \mathrm{K}$ and $\mathrm{Ca}$.

Using XRD, scanning electron microscopy (SEM), energy dispersive X-ray spectroscopy (EDS) and Raman microspectroscopy, Sobanska et al. (1999) estimated individual particles of air pollution control particles from a lead smelter to comprise amounts of $\mathrm{PbS}, \mathrm{PbSO}_{4}, \mathrm{PbSO}_{4} \cdot \mathrm{PbO}$, $\mathrm{ZnS}, \mathrm{ZnO}, \mathrm{CdS}$ and $\mathrm{CdSO}_{4}$ in the range $15-$ $60 \%$. They also determined elemental compositions using bulk chemical analysis, obtaining close to $100 \%$ mass balances.

Ettler et al. (2005) used bulk chemical analysis, XRD analysis, SEM, transmission electron microscopy (TEM) and EPMA to identify the phases in four samples of particulate matter from the various stages of air pollution control in a lead smelter in the Czech Republic. The samples consisted of major amounts of such phases as quartz $\left(\mathrm{SiO}_{2}\right)$, anglesite $\left(\mathrm{PbSO}_{4}\right)$, cotunnite $\left(\mathrm{PbCl}_{2}\right)$, minor amounts of $\mathrm{K}$-feldspar $\left(\mathrm{KAlSi}_{3} \mathrm{O}_{8}\right)$, la-

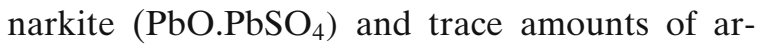
senolite $\left(\mathrm{As}_{2} \mathrm{O}_{3}\right)$ and senarmonite $\left(\mathrm{Sb}_{2} \mathrm{O}_{3}\right)$. From their bulk chemical analysis, they determined the concentrations of the elements in the four samples. While they qualitatively identified the sample phases, it might have been useful to quantify the amounts of each phase. Again, Ettler et al. (2008) used Rietveld XRD to quantitatively identify major amounts of $\mathrm{Na}_{2} \mathrm{SO}_{4} \cdot \mathrm{NaCl} \cdot 2 \mathrm{PbSO}_{4}$, $\mathrm{KCl} .2 \mathrm{PbCl}_{2}, \mathrm{NaCl}$ and $\mathrm{Na}_{2} \mathrm{SO}_{4}$ in the crystalline fractions of two samples of lead smelter airpollution-control residues.

Sánchez de la Campa et al. (2008) and SánchezRodas et al. (2007) focused on arsenic speciation in PM2.5 and PM10 samples collected near a copper smelter. They found that $\mathrm{As}(\mathrm{V})$ was the predominant species, accounting for $79-84 \%$ of the total, with As(III) comprising the balance. Knowledge of the compounds associated with the arsenic, while of interest, was likely prevented by the practical difficulties in collecting samples in quantities sufficient for analysis. The practical difficulties in collecting sufficient sample quantities may have prevented a determination of the compounds associated with the arsenic.

Wong et al. (2006) determined the mass fractions of $\mathrm{As}, \mathrm{Cd}, \mathrm{Cu}, \mathrm{Ni}, \mathrm{Pb}, \mathrm{Se}$ and $\mathrm{Zn}$ in mid-stack particulate samples and downstream plumes from a copper smelter. At $0.31-0.41$ and $0.14-0.43$ mass fractions, respectively, $\mathrm{Pb}$ and $\mathrm{As}$ were dominant elements in the mid-stack particulate samples, followed by $\mathrm{Cu}$ at $0.11-0.30$ and $\mathrm{Zn}, 0.07-$ 0.20 . Working with very small sample sizes, they would have considerable difficulty in determining the speciation and compounds of As and the metals.

Beavington et al. (2004) measured the concentrations of trace elements $\mathrm{Cr}, \mathrm{Zn}, \mathrm{Ag}, \mathrm{Se}, \mathrm{Cd}$, $\mathrm{Sb}, \mathrm{Au}$ and $\mathrm{Pb}$ in the atmosphere near a copper smelter. Again, lack of sufficient sample may have prevented a determination of speciation and compounds.

In examining the electrostatic dust samples from a copper-nickel smelter, Barcan (2002) quantified several elements, such as $\mathrm{As}, \mathrm{Cu}, \mathrm{Ni}, \mathrm{Pb}$ and $\mathrm{Zn}$, and qualitatively identified phases such as pentlandite ( $\mathrm{Fe}, \mathrm{Ni})_{9} \mathrm{~S}_{8}$, pyrrhotite $\mathrm{Fe}_{7} \mathrm{~S}_{8}, \mathrm{As}_{2} \mathrm{O}_{5}$, khyslevudite $\mathrm{Ni}_{3} \mathrm{~S}_{2}, \mathrm{PbO}, \mathrm{ZnO}$, cuprite $\mathrm{Cu}_{2} \mathrm{O}$, tenorite $\mathrm{CuO}$ and silicates of $\mathrm{Fe}, \mathrm{As}, \mathrm{Mg}$ and $\mathrm{Ca}$. A quantitative assessment of the identified phases would have been of interest.

Karczewska (1996) used sequential extraction to determine the distribution of eight metals including $\mathrm{Cu}, \mathrm{Pb}$ and $\mathrm{Zn}$ in soil samples near a copper smelter. She found that $40-50 \%$ of the $\mathrm{Cu}$ and $\mathrm{Pb}$ were in the mobile and exchangeable fractions of strongly polluted sandy soils. However, the compounds with which the metals were associated remained unidentified.

Gieré et al. (2006) used TEM to identify the amorphous and crystalline phases in collected PM2.5 from a coal combustion station stack in which tires were experimentally combusted. The amorphous phases comprised silicates and sulphates of $\mathrm{Al}, \mathrm{K}, \mathrm{Fe}, \mathrm{Na}$ and $\mathrm{Zn}$. Among the crystalline phases were anglesite $\mathrm{PbSO}_{4}$, gunningite $\mathrm{ZnSO}_{4} \cdot 2 \mathrm{H}_{2} \mathrm{O}$ and anhydrite $\mathrm{CaSO}_{4}$. Of interest would have been the quantities of the amorphous and crystalline phases.

Thus, a limited amount of quantitative data on smelter particulates is available for elemental analyses, while speciation data tend to be qualitative or at best semi-quantitative. Analysis of smelter particulates to determine how they were formed and their chemical composition would be of considerable value in determining treatment 
methods and in predicting environmental effects (Samuelsson and Björkman 1998).

The objective of this study was to develop quantitative chemical speciation of the stack particulates from three copper smelters, including a mass balance as close to $100 \%$ as possible. While we have applied it to stack particulate samples from copper smelters, the new method could equally be applied to stack particulates from any non-ferrous or ferrous smelting operation. By chemical speciation, we mean a characterisation of the compounds or dissolved species that comprise a solid or solution. The stack particulates may be considered as potential sources of metals released as compounds to the atmosphere.

\section{Materials and methods}

Samples of Smelter Stack Particulates The samples of smelter stack particulates were from three copper smelters designated as A, B and C. The C smelter process consists of smelting copper concentrate in a Teniente converter and flash furnace followed by Peirce-Smith conversion and anodic furnace casting of blister copper. An electric furnace is used for slag cleaning. The A smelter process is similar to that for the $\mathrm{C}$ smelter, except that smelting is conducted in Teniente furnaces only and a tilting furnace is used for slag cleaning. The B smelter process is much the same as at the A smelter.

During continuous operation at all three smelters, the primary off-gases from the Teniente converters and Peirce-Smith converters pass through electrostatic precipitators and are combined and proceed to acid plants for conversion to $\mathrm{H}_{2} \mathrm{SO}_{4}$. However, following process interruption for routine maintenance, the converters and furnaces are returned to operational temperatures by heating with natural gas and, since they are unsuitable for acid plant treatment, these gases are diverted to the primary stack, which is cleared of particulates about once per month. The particulate samples under consideration here were removed from the interior walls of these primary stacks, from the A and C smelters in February, 2005, and from the B smelter in April, 2004. The samples may be considered as surrogates for particulates released to the atmosphere aggregated over the period of about 1 month.

Bulk Chemical Analysis We determined the total percentages of $\mathrm{Al}_{2} \mathrm{O}_{3}, \mathrm{As}, \mathrm{CaO}, \mathrm{Cd}, \mathrm{Cr}_{2} \mathrm{O}_{3}, \mathrm{Cu}$, $\mathrm{Fe}, \mathrm{K}_{2} \mathrm{O}, \mathrm{MgO}, \mathrm{Na}_{2} \mathrm{O}, \mathrm{Ni}, \mathrm{Pb}, \mathrm{SiO}_{2}$, total $\mathrm{S}, \mathrm{SO}_{4}$, $\mathrm{Sb}$, Se and $\mathrm{Zn}$ in the as-received (a-r) particulates by bulk chemical analysis. In Appendix 1, we have presented an overview of the analytical methods, limits of quantification (LOQs) and estimates of uncertainties in the analyses and in the quantitative speciation.

Leaching Procedure To obtain an indication of their behaviour upon contact with aqueous media, the extent to which they contain soluble material, and whether the media would affect particulate reactivity, we also subjected the smelter particulates to leaching in three media: (1) the OECD (Organization for Economic Cooperation and Development) 203 aquatic ecotoxicity testing medium for fish and Daphnia (OECD 1992); (2) $18 \mathrm{M} \Omega$ deionised (d.i.) water and (3) RICH-95, a reference lake water obtained from Environment Canada's NWRI (National Water Research Institute). The compositions of the OECD 203 and the RICH-95 aqueous media are presented in Tables 1 and 2, respectively.

The leaching procedure was adapted from the UN Transformation/Dissolution Protocol for Metals and Sparingly Soluble Inorganic Metal compounds (United Nations 2009), that had been originally developed within the framework of the OECD (2001). The procedure consisted of agitating weighed quantities of a-r particulates in the leaching media at $200 \mathrm{rpm}$ in the temperature range $22.4-25.3^{\circ} \mathrm{C}$ for $6 \mathrm{~h}$, and filtering the resulting slurry through a $90-\mathrm{mm}$ diameter $0.45-\mu \mathrm{m}$ Acrodisc filter. We then acidified the filtrate to $\mathrm{pH} \sim 1$ and analysed for total dissolved $\mathrm{Al}$, As, $\mathrm{Ca}, \mathrm{Cd}, \mathrm{Cr}, \mathrm{Cu}, \mathrm{Fe}, \mathrm{K}, \mathrm{Mg}, \mathrm{Na}, \mathrm{Ni}, \mathrm{Pb}$, total $\mathrm{S}$, $\mathrm{SO}_{4}, \mathrm{Sb}, \mathrm{Se}$ and $\mathrm{Zn}$. We also thoroughly rinsed the residue, allowed it to air-dry and used bulk chemical analysis for $\mathrm{Al}_{2} \mathrm{O}_{3}, \mathrm{As}, \mathrm{CaO}, \mathrm{Cd}, \mathrm{Cr}_{2} \mathrm{O}_{3}$, $\mathrm{Cu}, \mathrm{Fe}, \mathrm{K}_{2} \mathrm{O}, \mathrm{MgO}, \mathrm{Na}_{2} \mathrm{O}, \mathrm{Ni}, \mathrm{Pb}$, total $\mathrm{S}, \mathrm{SO}_{4}$, $\mathrm{Sb}$, Se and $\mathrm{Zn}$. Ideally, a minimum of $5 \mathrm{~g}$ of postleach residue should be available for bulk chemical analysis of the residues. A reasonable initial 
Table 1 Composition of modified OECD 203 (ISO 6341) aqueous medium (no micronutrients)

\begin{tabular}{|c|c|c|c|c|c|c|c|c|c|c|}
\hline Component & M.W. & $\mathrm{mg} / \mathrm{L}$ & $\mathrm{Mg}^{2+}$ & $\mathrm{Ca}^{2+}$ & $\mathrm{Cl}^{-}$ & $\mathrm{HCO}_{3}^{-}$ & $\mathrm{SO}_{4}^{2-}$ & $\mathrm{Na}^{+}$ & $\mathrm{K}^{+}$ & $\mathrm{mmol} / \mathrm{L}$ \\
\hline $\mathrm{CaCl}_{2} \cdot 2 \mathrm{H}_{2} \mathrm{O}$ & 147.01 & 294.00 & & 80.15 & 141.80 & & & & & 2.00 \\
\hline $\mathrm{MgSO}_{4} \cdot 7 \mathrm{H}_{2} \mathrm{O}$ & 246.47 & 123.25 & 12.15 & & & & 48.04 & & & 0.50 \\
\hline $\mathrm{NaHCO}_{3}$ & 84.01 & 64.75 & & & & 47.03 & & 17.72 & & 0.77 \\
\hline $\mathrm{KCl}$ & 74.55 & 5.75 & & & 2.73 & & & & 3.02 & 0.077 \\
\hline \multirow{2}{*}{\multicolumn{2}{|c|}{$\begin{array}{l}\text { Totals, mg/L } \\
\mathrm{mmol} / \mathrm{L}\end{array}$}} & & 12.15 & 80.15 & 144.53 & 47.03 & 48.04 & 17.72 & 3.02 & \\
\hline & & & 0.50 & 2.00 & 4.08 & 0.771 & 0.50 & 0.771 & 0.077 & \\
\hline \multicolumn{2}{|c|}{ Hardness as $\mathrm{CaCO}_{3}, \mathrm{mg} / \mathrm{L}$} & 250 & & & & & & & & \\
\hline
\end{tabular}

Reference: http://www.oecd.org/dataoecd/17/20/1948241.pdf; Calculated pH of medium when in equilibrium with air $\left(0.038 \% \mathrm{CO}_{2}\right)$ at $21.5^{\circ} \mathrm{C}: 8.00$ (FactSage 6.2. 2009. www.factsage.com)

assumption is that about $50 \%$ of the smelter stack particulates will dissolve during leaching, so a minimum of $10 \mathrm{~g}$ of sample should be available for each leaching test. For $10 \mathrm{~g}$ weights, we prepared initial media volumes of $850 \mathrm{~mL}$, and for the more ideal weights of $20 \mathrm{~g}, 1,800 \mathrm{~mL}$, adjusting the final volumes to 1,000 and $2,000 \mathrm{~mL}$, respectively, after filtration.

$X R D$ We obtained XRD patterns of the a-r particulate samples and the leach residues using an automated $12 \mathrm{~kW}$ rotating anode Rigaku X-ray diffractometer, and achieved phase identification with the JADE version 9.0 interfaced with the Inorganic Crystal Structure Database and International Centre for Diffraction Data diffraction databases.

SEM/EPMA We further characterised the a-r particulate materials using a JEOL JXA 8900 electron microprobe that we used as an SEM and as an EPMA. We obtained backscattered electron (BSE) images and performed X-ray microanalyses by EDS and wavelength-dispersive (WDS) spectroscopy. Most of this microcharacterisation was done on pristine powder samples mounted on conductive tape to reveal the morphology of the particulates in greater detail. Typically, on such rough surfaces, only qualitative EDS analyses can be achieved. Nevertheless, we also used WDS scans to resolve significant energy overlaps between some of the major elements (e.g. $\mathrm{Pb} \mathrm{M}$ with $\mathrm{S} \mathrm{K}$; Pb L with As $\mathrm{K}$ and $\mathrm{Zn} \mathrm{K}$ with $\mathrm{Na} \mathrm{K}$ ) and to confirm the presence of oxygen.

We also made polished mounts by embedding a portion of each particulate sample in epoxy. To prevent contact with water, we polished the mounts in alcohol and oil. Although the surface quality was not ideal, mainly due to the finegrained nature of the materials, this approach allowed the quantitative analyses of some of the phases by WDS.

For the silicate analyses, the EPMA was operated with an accelerating voltage of $15 \mathrm{kV}$, a probe current of 5-10 nA and counting times of 10 to 30 s. Characteristic X-ray lines and standards used were: $\mathrm{Si} \mathrm{K} \alpha$ (Orthoclase), $\mathrm{Al} \mathrm{K} \alpha$ (Orthoclase), Fe $\mathrm{K} \alpha$ (Almandine), $\mathrm{Cu} \mathrm{K} \alpha\left(\mathrm{Cu}_{2} \mathrm{O}\right), \mathrm{Zn} \mathrm{L} \alpha(\mathrm{ZnO})$, $\mathrm{Pb} \mathrm{M} \alpha\left(\mathrm{PbSO}_{4}\right), \mathrm{CaK} \alpha$ (Wollastonite), $\mathrm{Na} \mathrm{K} \alpha$ (albite), K K $\alpha$ (orthoclase), As L $\alpha$ (FeAs2), S K $\alpha$ $\left(\mathrm{PbSO}_{4}\right)$. An overlap correction was applied to account for the interference of $\mathrm{Zn} \mathrm{L} \beta$ on $\mathrm{Na} \mathrm{K} \alpha$.

Table 2 Composition of RICH-95 National Water Research Institute certified reference Lake Water, Environment Canada

\begin{tabular}{|c|c|c|c|c|c|c|c|c|c|}
\hline & & \multirow[t]{2}{*}{$\mathrm{Mg}^{2+}$} & \multirow[t]{2}{*}{$\mathrm{Ca}^{2+}$} & \multirow[t]{2}{*}{$\mathrm{Cl}^{-}$} & \multirow[t]{2}{*}{$\mathrm{SO}_{4}^{2-}$} & \multirow[t]{2}{*}{$\mathrm{Na}^{+}$} & \multirow[t]{2}{*}{$\mathrm{K}^{+}$} & \multicolumn{2}{|c|}{ Dissolved carbon } \\
\hline & & & & & & & & Inorganic & Organic \\
\hline Totals, mg/L & & 7.89 & 27.55 & 18.51 & 18.00 & 13.26 & 2.39 & 18.43 & 3.50 \\
\hline $\mathrm{Mmol} / \mathrm{L}$ & & 0.32 & 0.69 & 0.52 & 0.19 & 0.58 & 0.06 & 1.53 & 0.29 \\
\hline Hardness as $\mathrm{CaCO}_{3}, \mathrm{mg} / \mathrm{L}$ & 101 & & & & & & & & \\
\hline
\end{tabular}

Calculated $\mathrm{pH}$ of medium when in equilibrium with air $\left(0.038 \% \mathrm{CO}_{2}\right)$ at $21.5^{\circ} \mathrm{C}: 8.29$ (FactSage 6.2. 2009. www.factsage.com) 
An accelerating voltage of $20 \mathrm{kV}$ with a probe current of $10 \mathrm{nA}$ and counting times ranging from 20 to $30 \mathrm{~s}$ were used for the $\mathrm{Cu}$ oxides, sulphides and arsenates analyses. The characteristic X-ray lines and standards used were: $\mathrm{Cu} \mathrm{K} \alpha$ $\left(\mathrm{Cu}_{2} \mathrm{O}, \mathrm{CuS}\right), \mathrm{Zn} \mathrm{K} \alpha(\mathrm{ZnO})$, As $\mathrm{L} \alpha$ (FeAs2), $\mathrm{O} \mathrm{K} \alpha\left(\mathrm{Cu}_{2} \mathrm{O}\right)$. Potential $\mathrm{O} \mathrm{K} \alpha$ and $\mathrm{S} \mathrm{K} \alpha$ peak shift in the various phases were monitored and accounted for.

Quantitative speciation calculation Using a stepwise apportioning procedure, we developed the quantitative speciation of the particulate samples by assigning the metals and other analytes to specific phases and compounds on the basis of the results of the bulk chemical analyses, mass balances, XRD, and SEM/EPMA data. A worked example of the step-wise procedure is in Appendix 2. We have assigned the minor and trace metals such as $\mathrm{Al}, \mathrm{Fe}, \mathrm{Sb}$ and $\mathrm{Si}$ (but not $\mathrm{Ag}$ ) to oxides since it is most unlikely that they would exist in the elemental state in the a-r particulates. Moreover, while we present the amounts of these oxides in percentages, they may not necessarily exist as separate and discrete phases, but may rather be associated as agglomerates with other minor and trace oxides or with the major phases.

Mass balance calculations Mass balances are important to ensure that we can provide an accounting of the amounts of a particular analyte in the a-r particulates against the corresponding amounts in the leach residue and leachate. A mass balance close to $100 \%$, particularly for the major analytes, provides a validation of our quantitative speciation calculations and an assurance that we have accounted for most or all of the specified analyte between a-r particulates on the one hand and residues plus leachate on the other hand.

As per Appendix 2, the mass balance for any analyte is given by

mass balance

$$
=100 \times \frac{\frac{\text { moles leached }}{100 \mathrm{~g} \text { sample }}+\frac{\text { moles in residue }}{100 \mathrm{~g} \text { sample }}}{\frac{\text { moles in a-r particulates }}{100 \mathrm{~g} \text { sample }}} .
$$

\section{Results and discussion}

A smelter

Chemical composition of a-r particulates The bulk chemical analyses of Table 3 reveal that, in addition to $\mathrm{SO}_{4}$ at $34.7 \%$, the a-r A smelter particulate sample is dominated by $\mathrm{Cu}, \mathrm{Pb}, \mathrm{As}$ and $\mathrm{Zn}$, in weight percentages of 20.5, 7.5, 6.6 and 6.6, respectively. We also detected trace and minor amounts of $\mathrm{Cr}, \mathrm{Ni}, \mathrm{Se}, \mathrm{Ag}, \mathrm{Sb}, \mathrm{Mg}, \mathrm{C}, \mathrm{Al}, \mathrm{Ca}, \mathrm{Si}$, $\mathrm{Na}, \mathrm{Fe}$ and $\mathrm{K}$ in the range $0.0009 \%$ to $1.79 \%$.

Leaching results and mass balances The percentage distributions of the analytes between the leachates from leaching with OECD 203, d.i. water and the RICH-95 medium and corresponding residues, as well as the mass balances for each analyte are also in Table 3. The distributions of the analytes $\mathrm{As}, \mathrm{Cu}$ and $\mathrm{SO}_{4}$ between the leachates and the residues indicate that averages of about $47 \%, 57 \%$ and $99 \%$, respectively, dissolved during the leach tests. Almost all of the $\mathrm{Pb}$ reported to the residue. These distributions are supported by their mass balances being close to $100 \%$. However, the mass balance for $\mathrm{Zn}$ was about $122 \%$, so that the calculated $\sim 110 \%$ level in the leachates is only a qualitative indication of a relatively high dissolution value. An average of about $65 \%$ of the total weights of the samples was leached.

The mass balances for the trace and minor components $\mathrm{Ag}, \mathrm{Al}, \mathrm{Cd}, \mathrm{Fe}, \mathrm{K}, \mathrm{Mg}, \mathrm{Na}, \mathrm{Ni}$, and $\mathrm{Sb}$ were all within $86-124 \%$, so the distributions between leachate and residue can be considered credible, the more so because of the relatively low concentrations of each analyte. Even for the trace element $\mathrm{Cr}$, the mass balances were between $104 \%$ and $135 \%$. For $\mathrm{Ca}$ in the d.i. $\mathrm{H}_{2} \mathrm{O}$ and $\mathrm{RICH}$ 95 lixiviants, the mass balances were $100 \%$ and $93 \%$, respectively. However, subtracting the relatively high value of $\mathrm{Ca}$ in the OECD 203 lixiviant from the measured concentration in the OECD leachate reduced its mass balance to $79 \%$. The mass balances in the range $32 \%$ to $38 \%$ for $\mathrm{Se}$ were the only ones to reflect the difficulty in obtaining $\sim 100 \%$ values for minor or trace analytes.

Mineralogical analyses We used XRD and SEM/ EPMA characterisation to help assign the analytes 
Table 3 Chemical analysis of A smelter stack particulates and percentage distributions of analytes between leachates and residues

\begin{tabular}{|c|c|c|c|c|c|c|c|c|c|c|}
\hline \multirow{2}{*}{\multicolumn{2}{|c|}{$\begin{array}{l}\text { A smelter } \\
\text { as-received }\end{array}$}} & \multicolumn{9}{|l|}{ Leached in } \\
\hline & & \multicolumn{3}{|l|}{ OECD 203} & \multicolumn{3}{|l|}{ d.i. $\mathrm{H}_{2} \mathrm{O}$} & \multicolumn{3}{|l|}{ RICH 95} \\
\hline Analyte & wt. \% & \% Leached & $\begin{array}{l}\% \text { In } \\
\text { residue }\end{array}$ & $\begin{array}{l}\text { Mass } \\
\text { balance, \% }\end{array}$ & $\%$ Leached & $\begin{array}{l}\% \text { In } \\
\text { residue }\end{array}$ & $\begin{array}{l}\text { Mass } \\
\text { balance, \% }\end{array}$ & $\%$ Leached & $\begin{array}{l}\% \text { In } \\
\text { residue }\end{array}$ & $\begin{array}{l}\text { Mass } \\
\text { balance, \% }\end{array}$ \\
\hline As & 6.63 & 39.1 & 61.1 & 100 & 56.3 & 43.4 & 100 & 45.0 & 55.1 & 100 \\
\hline $\mathrm{Cu}$ & 20.49 & 55.34 & 42.07 & 97 & 59.40 & 43.07 & 102 & 54.94 & 42.81 & 98 \\
\hline $\mathrm{Zn}$ & 6.56 & 110 & 11 & 121 & 114 & 9.28 & 123 & 111 & 10.4 & 122 \\
\hline $\mathrm{Ni}$ & 0.0039 & 51 & 46 & 97 & 53 & 57 & 111 & 51 & 47 & 98 \\
\hline $\mathrm{Pb}$ & 7.49 & 0.0021 & 99.2 & 99 & 0.0043 & 97.0 & 97 & 0.0021 & 98.96 & 99 \\
\hline $\mathrm{Cd}$ & 0.386 & 84.0 & 12.3 & 96 & 90.9 & 8.58 & 99 & 86.7 & 10.1 & 97 \\
\hline $\mathrm{Se}$ & 0.009 & 4 & 31 & 35 & 8 & 30 & 38 & 4 & 28 & 32 \\
\hline $\mathrm{Sb}$ & 0.16 & 2.0 & 108 & 110 & 6.0 & 103 & 109 & 4.3 & 103 & 107 \\
\hline $\mathrm{Ag}$ & 0.024 & 0.47 & 94 & 95 & 0.12 & 92 & 93 & 0.11 & 96 & 97 \\
\hline $\mathrm{Cr}$ & 0.0009 & 0.4 & 103 & 104 & 0.8 & 134 & 135 & 0.4 & 111 & 112 \\
\hline $\mathrm{Fe}$ & 1.29 & 0.0536 & 91.8 & 92 & 1.14 & 85.4 & 86 & 0.125 & 89.8 & 90 \\
\hline $\mathrm{C}$ & 0.19 & & & & & & & & & \\
\hline $\mathrm{Al}$ & 0.193 & 2.08 & 120 & 122 & 13.5 & 105 & 119 & 8.63 & 113 & 121 \\
\hline $\mathrm{Ca}$ & 0.577 & 72.9 & 6.09 & 79 & 94.3 & 5.27 & 100 & 87.1 & 5.41 & 93 \\
\hline $\mathrm{Mg}$ & 0.185 & 89.0 & 10.4 & 99 & 114 & 10.0 & 124 & 97.7 & 10.4 & 108 \\
\hline K & 1.79 & 97.5 & 5.59 & 103 & 97.9 & 5.10 & 103 & 97.5 & 5.60 & 103 \\
\hline $\mathrm{Na}$ & 0.935 & 109 & 1.37 & 111 & 114 & 1.22 & 115 & 110 & 1.33 & 111 \\
\hline $\mathrm{SO}_{4}$ & 34.71 & 98.84 & 9.731 & 109 & 97.49 & 10.06 & 108 & 100.84 & 9.879 & 111 \\
\hline $\mathrm{Si}$ & 0.757 & & & & & & & & & \\
\hline \multirow[t]{3}{*}{ Total } & 82.38 & \multicolumn{2}{|c|}{ Initial wt., g: } & 10.0007 & Initial wt., $\mathrm{g}$ : & & 10.0182 & \multicolumn{2}{|c|}{ Initial wt., g: } & 10.0107 \\
\hline & & \multirow{2}{*}{\multicolumn{2}{|c|}{$\begin{array}{l}\text { Residue wt., g: } \\
\text { \% Leached }\end{array}$}} & 3.7242 & Residue wt., & & 3.3527 & \multirow{2}{*}{\multicolumn{2}{|c|}{ Residue wt., g: }} & 3.5795 \\
\hline & & & & 62.76 & \% Leached & & 66.53 & & & 64.24 \\
\hline \multicolumn{2}{|c|}{ Initial pH } & \multicolumn{2}{|c|}{7.89} & & 4.94 & & & \multicolumn{2}{|c|}{7.86} & \\
\hline \multicolumn{2}{|c|}{ Final pH } & \multicolumn{2}{|l|}{4.02} & & 3.65 & & & \multicolumn{2}{|l|}{3.86} & \\
\hline
\end{tabular}

to specific phases/compounds. Whereas XRD is especially useful for identifying crystalline assemblages, SEM/EPMA allows the determination of the morphology and the chemical composition of the crystalline as well as potentially amorphous phases.

For the a-r A smelter stack particulates, the crystalline phases identified by XRD, Fig. 1a, are anglesite $\left(\mathrm{PbSO}_{4}\right)$, cuprite $\left(\mathrm{Cu}_{2} \mathrm{O}\right)$, gunningite $\left(\mathrm{ZnSO}_{4} \cdot \mathrm{H}_{2} \mathrm{O}\right)$, chalcocyanite $\left(\mathrm{CuSO}_{4}\right)$ and arsenolite $\left(\mathrm{As}_{2} \mathrm{O}_{3}\right)$. Moreover, the background profile of the XRD pattern suggests the presence of amorphous material.

The SEM/EPMA characterisation of the a-r sample confirms the presence of most of the crystalline phases identified by XRD, and suggests that they all have near end-member compositions with no significant solid solutions. The $\mathrm{Cu}$ sulphate and $\mathrm{Cu}$ oxide grains typically occur in 5 to
$10 \mu \mathrm{m}$ diameter spheroids (Fig. 2a, b). The EDS spectra, shown in Fig. 3a, b, indicate that they are fairly pure phases. WDS analyses indicate a $\mathrm{Cu}_{2} \mathrm{O}$ stoichiometry for the copper oxide (Table 4, Analysis \#1), consistent with the XRD data. Anglesite is homogeneously distributed throughout the sample as fine, often $\leq 1 \mu \mathrm{m}$, discrete grains that appear very bright in BSE images (e.g. Fig. 2a, c) due to the high atomic number of $\mathrm{Pb}$. EDS analysis suggests a pure $\mathrm{PbSO}_{4}$ chemistry (Fig. 3c) Arsenolite occurs as well-formed octahedral crystals (Fig. 2d) consisting only of As and $\mathrm{O}$ (Fig. 3d). Crystalline $\mathrm{Cu}$ sulphide with dendritic overgrowths (Fig. 2e), in abundance too low to be detected by XRD, was observed, and WDS characterisation supports a $\mathrm{Cu}_{2} \mathrm{~S}$ formula. Copper arsenate grains with minor amounts of $\mathrm{Zn}$, are also present. WDS analyses of a few larger grains indicate a composition close to olivenite, 

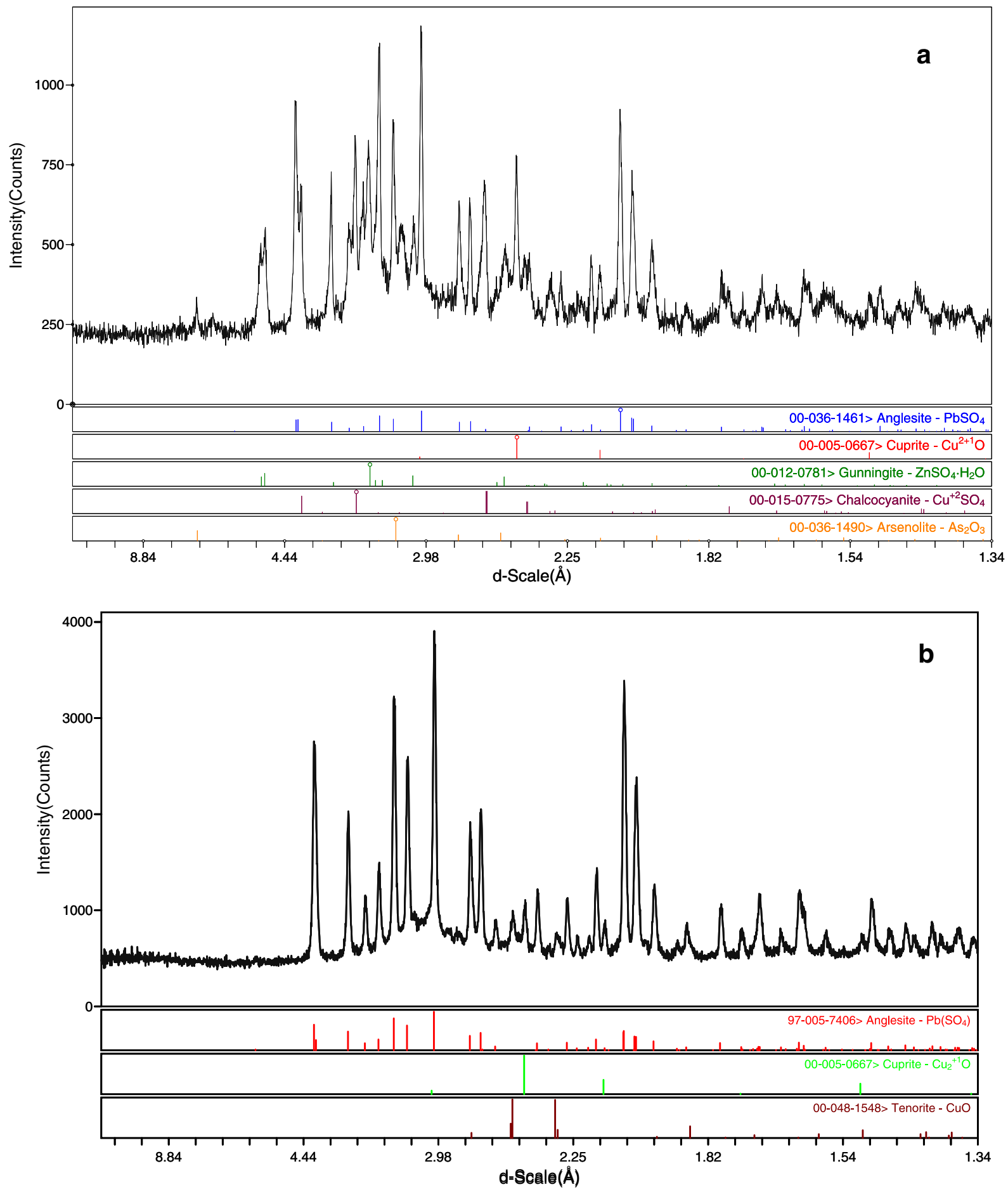

Fig. 1 XRD patterns of $\mathbf{a}$ the a-r A smelter stack particulates and $\mathbf{b}$ the residue from leaching of asample of the A smelter stack particulates in OECD 203 

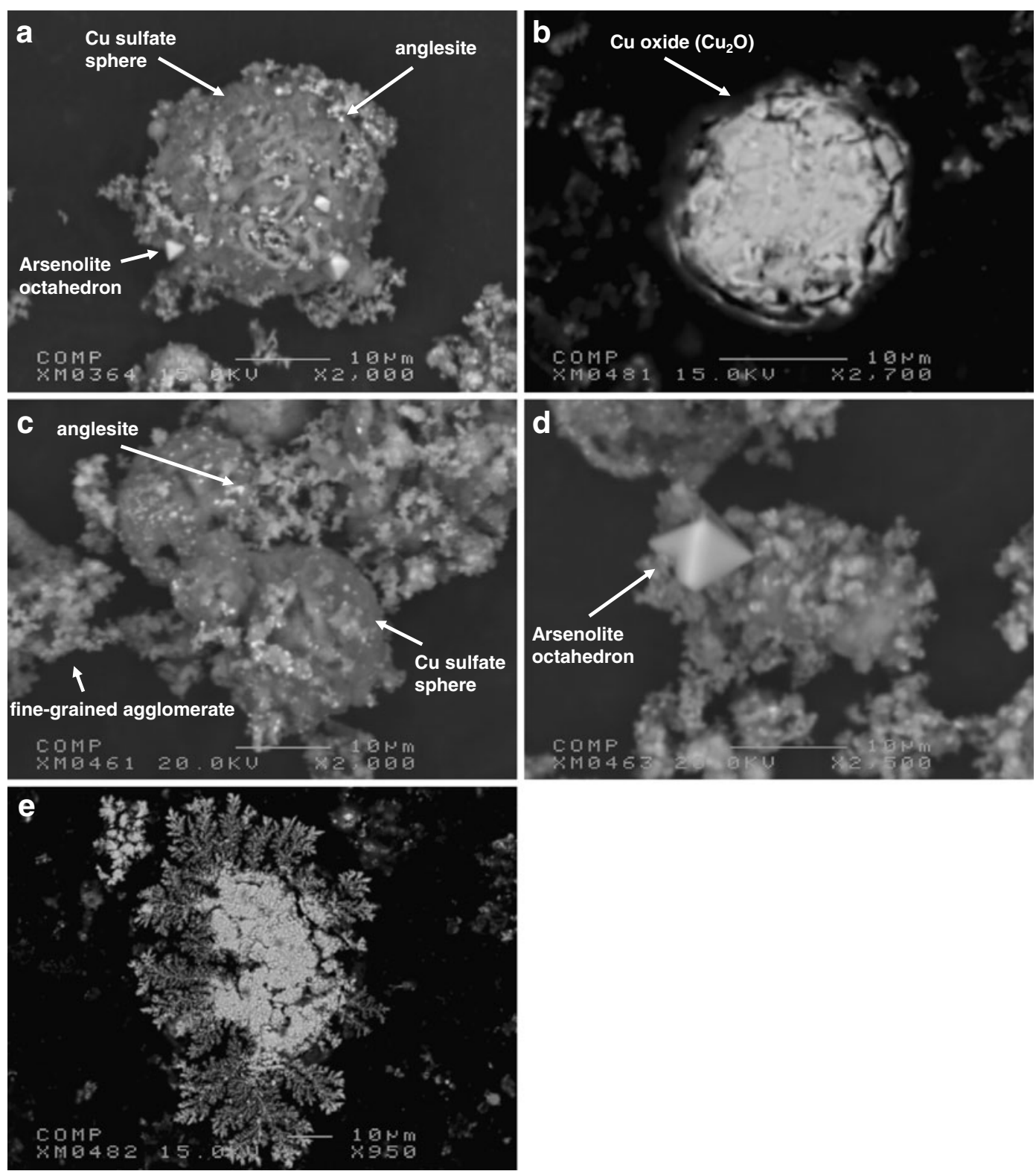

Fig. 2 BSE images of A smelter stack particulates: a $\mathrm{Cu}$ sulphate spheroid decorated with small arsenolite octahedra on a grain mount of the a-r material; $\mathbf{b} \mathrm{Cu}_{2} \mathrm{O}$ spheroid on a polished mount of the a-r material; $\mathbf{c}$ from a grain mount of the a-r sample, spheres of $\mathrm{Cu}$ sulphate and fine-grained agglomerate of sulphate material containing

$\left(\mathrm{Cu}_{\mathrm{x}} \mathrm{Zn}_{\mathrm{x}-1}\right)_{2}\left(\mathrm{AsO}_{4}\right)(\mathrm{OH})$, with $\mathrm{x}$ at about 0.94 and with minor $\mathrm{S}$ substituting for As (Table 4, Analysis \#3).

Additionally, phases of more complex compositions, some likely amorphous in nature, are

variable amounts of $\mathrm{Zn}, \mathrm{Cu}, \mathrm{K}, \mathrm{Na}$ and $\mathrm{As}$, both laced with small bright discrete grains of anglesite; $\mathbf{d}$ euhedral arsenolite octahedron attached to fine-grained agglomerate in a grain mount of the a-r material; $\mathbf{e} \mathrm{Cu}_{2} \mathrm{~S}$ grain with dendritic overgrowths in a polished mount of the a-r material

present. In particular, we observed a very finegrained agglomerate (Fig. 2c) whose composition determined by EDS suggests a sulphate with variable amounts of $\mathrm{Zn}, \mathrm{Cu}, \mathrm{K}, \mathrm{Na}$ and $\mathrm{As}$ and minor levels of $\mathrm{Si}, \mathrm{Ca}$ and $\mathrm{Fe}$ (Fig. 3e). The 

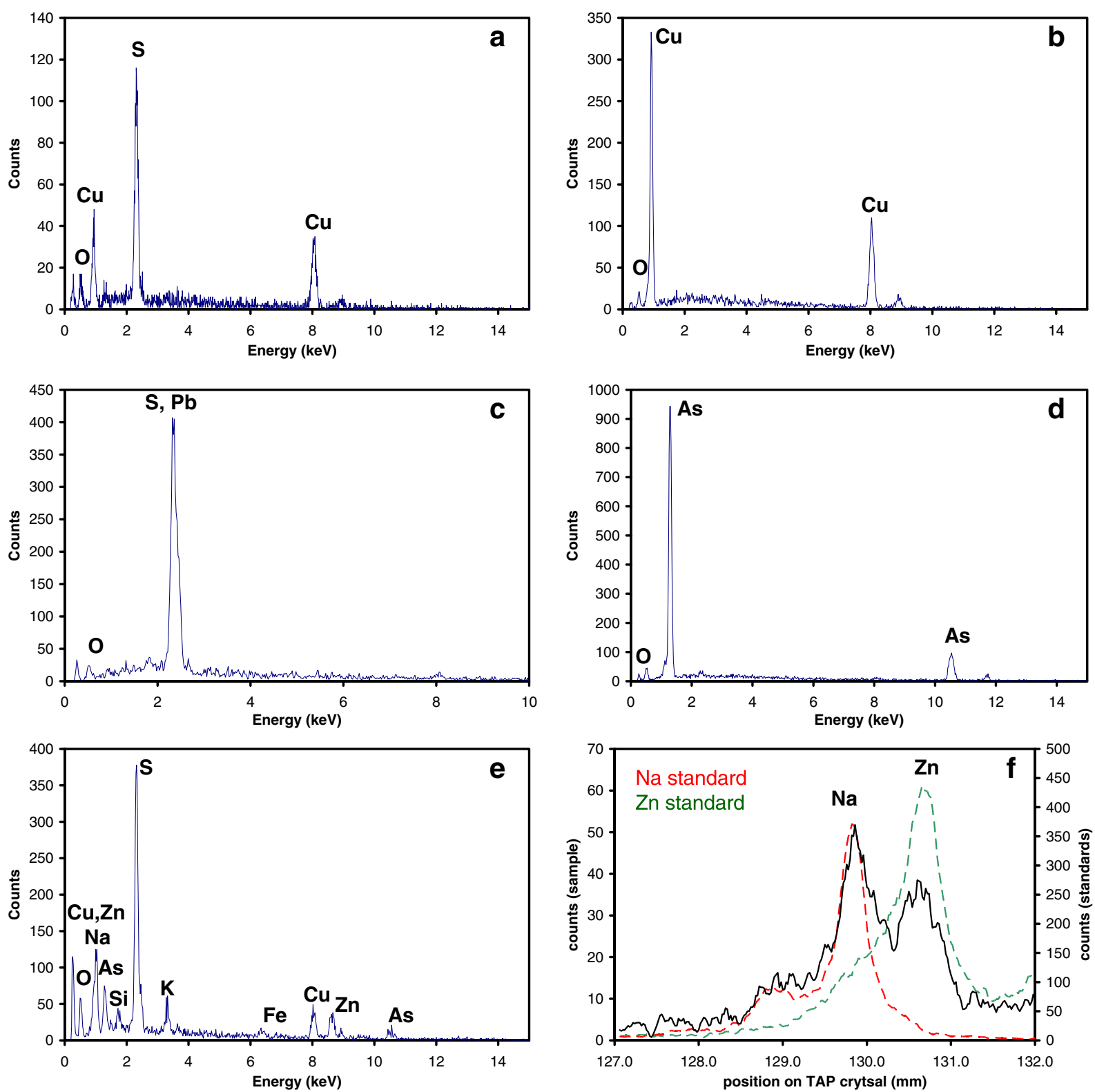

Fig. 3 EDS spectra obtained on grains of the A smelter stack particulates (note that EDS has Be window, so the response is poor for the low energy lines such as $\mathrm{O}$ ): a $\mathrm{Cu}$ sulphate shown in Fig. $2 \mathrm{a} ; \mathrm{b} \mathrm{Cu}$ oxide shown in Fig. 2b; c Anglesite shown in Fig. 2c; d Arsenolite shown in

Fig. 2d; e fine-grained agglomerate shown in Fig. 2c; $\mathbf{f}$ WDS spectrum in the energy region for $\mathrm{Na} K \alpha$ and $\mathrm{Zn}$ $\mathrm{L} \alpha$ obtained with a thallium phthalate (TAP) diffracting crystal for the fine-grained agglomerate shown in Fig. 2c confirming the presence of $\mathrm{Na}$

presence of $\mathrm{Na}$, which strongly overlaps with $\mathrm{Zn} \mathrm{L} \alpha$ in EDS, was revealed by a WDS scan (Fig. 3f). The fine-grained nature of this material prevents confirming if this represents one or

multiple phases, but there clearly appears to be a strong association, at least spatially, between $\mathrm{Zn}$ and the alkalis $\mathrm{Na}$ and $\mathrm{K}$, in the form of finegrained sulphate compounds, as per the calculated 
Table 4 Chemical composition of representative $\mathrm{Cu}$ oxide, sulphide and arsenates observed in a-r particulate samples

\begin{tabular}{|c|c|c|c|c|c|c|c|c|c|c|}
\hline & $\begin{array}{l}1 \\
\text { wt. \% }\end{array}$ & $\begin{array}{l}(N=9) \\
\text { S.D. }\end{array}$ & $\begin{array}{l}2 \\
\text { wt. } \%\end{array}$ & $\begin{array}{l}(N=10) \\
\text { S.D. }\end{array}$ & $\begin{array}{l}3 \\
\text { wt. \% }\end{array}$ & $\begin{array}{l}(N=5) \\
\text { S.D. }\end{array}$ & $\begin{array}{l}4 \\
\text { wt. \% }\end{array}$ & $\begin{array}{l}(N=4) \\
\text { S.D. }\end{array}$ & $\begin{array}{l}5 \\
\text { wt. \% }\end{array}$ & $\begin{array}{l}(N=3) \\
\text { S.D. }\end{array}$ \\
\hline $\mathrm{Cu}$ & 88.52 & 1.75 & 79.44 & 1.22 & 41.19 & 1.24 & 37.73 & 0.94 & 26.25 & 1.50 \\
\hline $\mathrm{Zn}$ & & & & & 2.57 & 0.42 & 0.58 & 0.32 & 5.20 & 0.85 \\
\hline As & & & & & 26.18 & 0.84 & 30.91 & 0.95 & 36.23 & 1.12 \\
\hline $\mathrm{S}$ & & & 20.17 & 0.81 & 0.45 & 0.13 & 0.51 & 0.11 & 0.80 & 0.21 \\
\hline $\mathrm{O}$ & 11.62 & 1.10 & & & 29.33 & 1.73 & 31.03 & 1.52 & 31.34 & 1.94 \\
\hline Total & 100.14 & & 99.61 & & 99.71 & & 100.76 & & 99.82 & \\
\hline \multicolumn{11}{|c|}{ Formula based on } \\
\hline & $2 \mathrm{Cu}$ & & $2 \mathrm{Cu}$ & & $1(\mathrm{As}+\mathrm{S})$ & & $2(\mathrm{As}+\mathrm{S})$ & & $1(\mathrm{As}+\mathrm{S})$ & \\
\hline $\mathrm{Cu}$ & 2.000 & & 2.000 & & 1.783 & & 2.772 & & 0.812 & \\
\hline $\mathrm{Zn}$ & & & & & 0.108 & & 0.042 & & 0.156 & \\
\hline $\mathrm{Cu}+\mathrm{Zn}$ & & & & & 1.891 & & 2.813 & & 0.969 & \\
\hline As & & & & & 0.962 & & 1.926 & & 0.951 & \\
\hline $\mathrm{S}$ & & & 1.007 & & 0.038 & & 0.074 & & 0.049 & \\
\hline $\mathrm{O}$ & 1.043 & & & & 5.043 & & 9.053 & & 3.853 & \\
\hline $\mathrm{Cu} /(\mathrm{Cu}+\mathrm{Zn})$ & & & & & 0.94 & & 0.99 & & 0.84 & \\
\hline $\mathrm{As} /(\mathrm{As}+\mathrm{S})$ & & & & & 0.96 & & 0.96 & & 0.95 & \\
\hline
\end{tabular}

The number of analyses (N) obtained for each phases is indicated together with the associated standard deviation (S.D.)

1: $\mathrm{Cu}$ oxide in a-r A sample; consistent with $\mathrm{Cu}_{2} \mathrm{O}$

2: Cu sulphide in a-r A sample; consistent with $\mathrm{Cu}_{2} \mathrm{~S}$

3: $\mathrm{Cu}$ arsenate in a-r A sample; close to $\left(\mathrm{Cu}_{0.94} \mathrm{Zn}_{0.06}\right)_{2}\left(\mathrm{AsO}_{4}\right)(\mathrm{OH})$

4: $\mathrm{Cu}$ arsenate in a-r B sample; close to $\left(\mathrm{Cu}_{0.98} \mathrm{Zn}_{0.02}\right)_{3}\left(\mathrm{AsO}_{4}\right)_{2} \cdot 2 \mathrm{H}_{2} \mathrm{O}$

5: $\mathrm{Cu}$ arsenate in a-r $\mathrm{C}$ sample; close to $\left(\mathrm{Cu}_{0.84} \mathrm{Zn}_{0.16}\right)\left(\mathrm{AsO}_{3} \mathrm{OH}\right)$

quantitative speciation. The presence of $\mathrm{Zn}$ sulphate in this agglomerate most likely represents gunningite, identified by XRD that cannot be resolved spatially with the SEM.

XRD analysis of the residue from leaching of the A smelter stack particulates in OECD 203 (Fig. 1b) reveals only the presence of anglesite and copper oxide, mainly cuprite, as crystalline phases. The lack of arsenolite in the XRD analysis is an indication of its ready solubility.

SEM/EPMA characterisation of a residue from leaching a sample of the A smelter particulates in d.i. water was also done. Grains of anglesite, copper oxide and copper arsenate were easily identified, thereby confirming their insoluble nature. Arsenolite grains and phases containing a significant amount of $\mathrm{Zn}$ and alkalis were not observed.

Quantitative speciation The step-wise apportioning procedure yields the following quantitative speciation for the a-r A smelter stack particulates, as presented in Table 5, as well as a combined relative uncertainty (c.r.u.) for each compound as derived in Appendix 1:

- $29 \% \mathrm{CuSO}_{4}$ (chalcocyanite, phase confirmed by XRD);

- $20 \% \mathrm{ZnSO}_{4} \cdot \mathrm{H}_{2} \mathrm{O}$ (gunningite, phase confirmed by XRD);

- $13 \%\left(\mathrm{Cu}_{0.94} \mathrm{Zn}_{0.06}\right)_{2}\left(\mathrm{AsO}_{4}\right)(\mathrm{OH})$ (based on WDS analyses of $\mathrm{Cu}$ arsenate grains);

- $11 \% \mathrm{PbSO}_{4}$ (anglesite, phase confirmed by XRD);

- $4.1 \% \mathrm{As}_{2} \mathrm{O}_{3}$ (arsenolite, phase confirmed by XRD);

- $3.9 \% \mathrm{~K}_{2} \mathrm{SO}_{4}$ (suggested by EDS data);

- $3.5 \% \quad \mathrm{Cu}_{2} \mathrm{O}$ (cuprite, phase confirmed by XRD and WDS data);

- $3.3 \% \mathrm{Na}_{2} \mathrm{SO}_{4}$ (suggested by EDS data);

- $1.6 \% \mathrm{Fe}_{2} \mathrm{O}_{3}$;

- $1.6 \% \mathrm{SiO}_{2}$;

and about less than $0.5 \%$ of each of $\mathrm{CdO}, \mathrm{Al}_{2} \mathrm{O}_{3}$, $\mathrm{ZnO}, \mathrm{Sb}_{2} \mathrm{O}_{5}, \mathrm{MgO}, \mathrm{PbO}, \mathrm{K}_{2} \mathrm{O}, \mathrm{Na}_{2} \mathrm{O}, \mathrm{Ag}, \mathrm{NiO}$, 


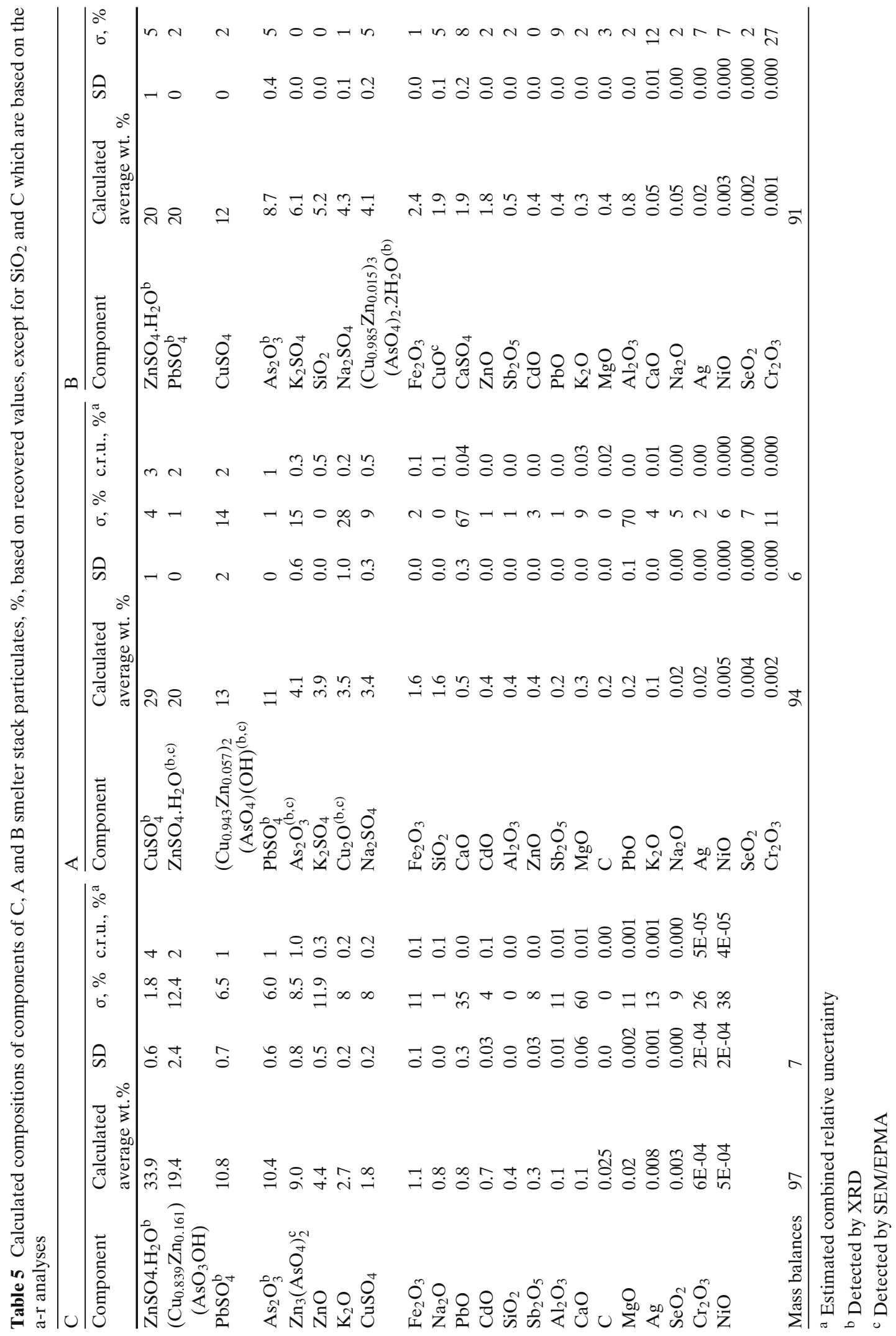


$\mathrm{SeO}_{2}$ and $\mathrm{Cr}_{2} \mathrm{O}_{3}$. The sum of the calculated total is $93 \%$, a reasonable result, considering the uncertainty in the phase compositions of some of the fine-grained amorphous material. Nonetheless, the calculation gives a good indication of the quantitative speciation of the A smelter stack particulates.

As per Table 3, the final $\mathrm{pH}$ values of the OECD 203, d.i. $\mathrm{H}_{2} \mathrm{O}$ and $\mathrm{RICH} 95$ leach media had declined to $4.02,3.65$ and 3.86 , respectively, due most likely to the dissolution of the $\mathrm{Cu}$ and $\mathrm{Zn}$ sulphates and the establishment of the equilibrium:

$\mathrm{H}^{+}+\mathrm{SO}_{4}^{2-}=\mathrm{HSO}_{4}^{-}$,

(reaction 1)

which introduces $\mathrm{H}^{+}$into solution, thereby decreasing its $\mathrm{pH}$.

The observations support the conclusion that $\mathrm{CuSO}_{4}, \mathrm{ZnSO}_{4}, \mathrm{~K}_{2} \mathrm{SO}_{4}, \mathrm{Na}_{2} \mathrm{SO}_{4}$ and most of the arsenolite will be soluble in aquatic media, whereas the $\mathrm{Cu}-\mathrm{Zn}$ arsenate, anglesite and cuprite will be preserved in the residue.

B smelter

Chemical composition of a-r particulates The chemical analyses of Table 6 reveal that the $\mathrm{B}$ smelter stack particulates contain about $32 \% \mathrm{SO}_{4}$, $8 \% \mathrm{As}$, and $8 \% \mathrm{Zn}$, all comparable to those of the A material, but are significantly leaner in $\mathrm{Cu}$ $(8 \%)$, and richer in $\mathrm{Pb}(14 \%)$ and $\mathrm{SiO}_{2}(5 \%)$. Minor and trace amounts of $\mathrm{Cr}, \mathrm{Sb}, \mathrm{Ag} \mathrm{Mg}, \mathrm{Cd}$, $\mathrm{Al}, \mathrm{Ca}, \mathrm{Na} \mathrm{Fe}$ and $\mathrm{K}$ were found in the range $0.0011 \%$ to $2.92 \%$. If $\mathrm{C}$ existed in the sample, it was below $0.01 \%$.

Leaching results and mass balances In Table 6, the distributions of the analytes between leachates

Table 6 Chemical analysis of B smelter stack particulates, and percentage distributions of analytes between leachates and residues

\begin{tabular}{|c|c|c|c|c|c|c|c|c|c|c|}
\hline \multirow{2}{*}{\multicolumn{2}{|c|}{$\begin{array}{l}\text { B smelter } \\
\text { as-received }\end{array}$}} & \multicolumn{9}{|l|}{ Leached in } \\
\hline & & \multicolumn{3}{|l|}{ OECD 203} & \multicolumn{3}{|l|}{ d.i. $\mathrm{H}_{2} \mathrm{O}$} & \multicolumn{3}{|l|}{ RICH 95} \\
\hline Analyte & wt. \% & \% Leached & $\begin{array}{l}\% \text { In } \\
\text { residue }\end{array}$ & $\begin{array}{l}\text { Mass } \\
\text { balance, \% }\end{array}$ & \% Leached & $\begin{array}{l}\% \text { In } \\
\text { residue }\end{array}$ & $\begin{array}{l}\text { Mass } \\
\text { balance, \% }\end{array}$ & \% Leached & $\begin{array}{l}\% \text { In } \\
\text { residue }\end{array}$ & $\begin{array}{l}\text { Mass } \\
\text { balance, \% }\end{array}$ \\
\hline As & 7.99 & 68.6 & 32 & 101 & 69.0 & 30.6 & 100 & 64.6 & 36.7 & 101 \\
\hline $\mathrm{Cu}$ & 7.88 & 60.0 & 39.9 & 100 & 61.4 & 35.5 & 97 & 59.1 & 39.7 & 99 \\
\hline $\mathrm{Zn}$ & 7.81 & 98.1 & 19 & 117 & 98.6 & 18.1 & 117 & 98.0 & 19.0 & 117 \\
\hline $\mathrm{Ni}$ & 0.0018 & 69 & 54 & 123 & 67 & 55 & 121 & 63 & 43 & 106 \\
\hline $\mathrm{Pb}$ & 13.96 & 0.0034 & 98.09 & 98 & 0.011 & 96.56 & 97 & 0.0033 & 99.85 & 100 \\
\hline $\mathrm{Cd}$ & 0.347 & 88.5 & 10.4 & 99 & 88.2 & 11.0 & 99 & 87.3 & 11.7 & 99 \\
\hline $\mathrm{Se}$ & 0.009 & 4 & 15 & 19 & 4 & 14 & 18 & 4 & 15 & 19 \\
\hline $\mathrm{Sb}$ & 0.32 & 2.5 & 107 & 109 & 2.7 & 103 & 105 & 2.9 & 104 & 107 \\
\hline $\mathrm{Ag}$ & 0.0209 & 0.086 & 95 & 95 & 0.02 & 83 & 83 & 0.017 & 99 & 99 \\
\hline $\mathrm{Cr}$ & 0.0011 & 4.5 & 70 & 74 & 5.3 & 116 & 121 & 4.0 & 63 & 67 \\
\hline $\mathrm{Fe}$ & 1.98 & 6.92 & 78.0 & 85 & 7.74 & 74.9 & 83 & 6.17 & 79.3 & 85 \\
\hline $\mathrm{C}$ & $<0.01$ & & & & & & & & & \\
\hline $\mathrm{Al}$ & 0.393 & 30.5 & 83.6 & 114 & 31.3 & 78.5 & 110 & 29.3 & 83.7 & 113 \\
\hline $\mathrm{Ca}$ & 0.662 & 77.0 & 6.57 & 84 & 94.2 & 5.81 & 100 & 88.6 & 6.20 & 95 \\
\hline $\mathrm{Mg}$ & 0.230 & 97.9 & 13.0 & 111 & 107 & 12.4 & 119 & 102 & 12.9 & 115 \\
\hline K & 2.92 & 94.3 & 8.40 & 103 & 95.0 & 8.39 & 103 & 94.0 & 8.75 & 103 \\
\hline $\mathrm{Na}$ & 1.27 & 108 & 3.20 & 111 & 110 & 3.12 & 113 & 108 & 3.27 & 111 \\
\hline $\mathrm{SO}_{4}$ & 32.26 & 89.88 & 19.17 & 109 & 90.73 & 18.89 & 110 & 89.33 & 19.62 & 109 \\
\hline $\mathrm{Si}$ & 2.42 & & & & & & & & & \\
\hline \multirow[t]{3}{*}{ Total } & 80.48 & & 20.0038 & \multicolumn{2}{|c|}{ Initial wt., g } & 20.0075 & & 20.0074 \\
\hline & & \multicolumn{2}{|c|}{ Residue wt., g } & 8.5122 & Residue wt., & & 8.2147 & \multicolumn{2}{|c|}{ Residue wt., g } & 8.7013 \\
\hline & & $\%$ Leached & & 57 & \% Leached & & 59 & $\%$ Leached & & 57 \\
\hline \multicolumn{2}{|c|}{ Initial $\mathrm{pH}$} & \multicolumn{2}{|c|}{7.90} & & \multicolumn{2}{|c|}{5.14} & & \multicolumn{2}{|l|}{8.05} & \\
\hline \multicolumn{2}{|c|}{ Final pH } & \multicolumn{2}{|l|}{2.88} & & \multicolumn{2}{|l|}{2.84} & & \multicolumn{2}{|l|}{2.97} & \\
\hline
\end{tabular}



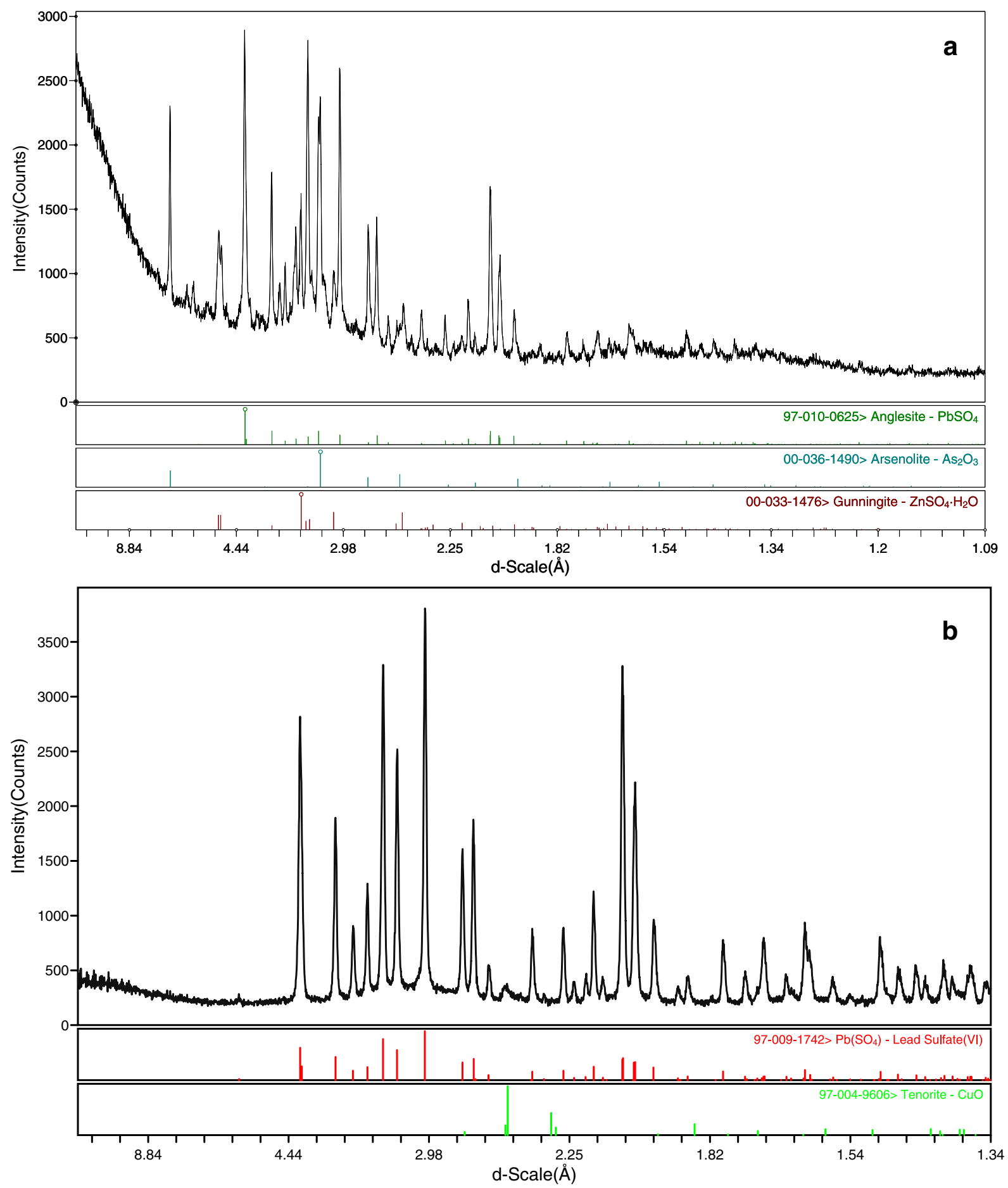

Fig. 4 XRD patterns of $\mathbf{a}$ the a-r B smelter stack particulates and $\mathbf{b}$ the residue from leaching of a sample of the B smelter stack particulates in OECD 203 
and residues show that averages of about $67 \%$, $60 \%$ and $90 \%$ of the $\mathrm{As}, \mathrm{Cu}$ and $\mathrm{SO}_{4}$, respectively, were leached, supported by mass balances of about $100 \%$ for $\mathrm{As}$ and $\mathrm{Cu}$, and $109 \%$ for $\mathrm{SO}_{4}$. As with the A smelter stack particulates, the calculated dissolution of $\mathrm{Pb}$ was less than $0.01 \%$, supported by a $\mathrm{Pb}$ mass balance close to $100 \%$. In contrast, on the basis of its concentrations in the leachates, Zn was almost $100 \%$ dissolved, although this value should be tempered by the $117 \%$ mass balance.

The distributions of the minor components $\mathrm{Al}_{2} \mathrm{O}_{3}, \mathrm{Ag}, \mathrm{Cd}, \mathrm{Fe}, \mathrm{Ni}, \mathrm{Sb}, \mathrm{Fe}, \mathrm{K}_{2} \mathrm{O}$ and $\mathrm{Na}_{2} \mathrm{O}$ between leachate and residue can be considered credible because their mass balances were all in the range $83-123 \%$. However, those for $\mathrm{Cr}, \mathrm{CaO}$,
$\mathrm{MgO}$ and Se reflect the difficulty in obtaining accurate analytical data at low concentrations.

Mineralogical analyses The major crystalline phases identified by XRD in the a-r B smelter particulates are gunningite, anglesite, and arsenolite, with a background profile of the XRD pattern suggesting the presence of amorphous material (Fig. 4a).

BSE imaging such as Fig. 5a and EDS analyses confirm the presence of anglesite and arsenolite as discrete phases with relatively pure compositions. Additional phases that appear crystalline, based on their morphology, are $\mathrm{Cu}_{2} \mathrm{~S}$ (Fig. 5b), as well as $\mathrm{Cu}_{2} \mathrm{O}$ and a copper arsenate (Fig. 5c). WDS analyses of a few copper arsenate grains indicate a
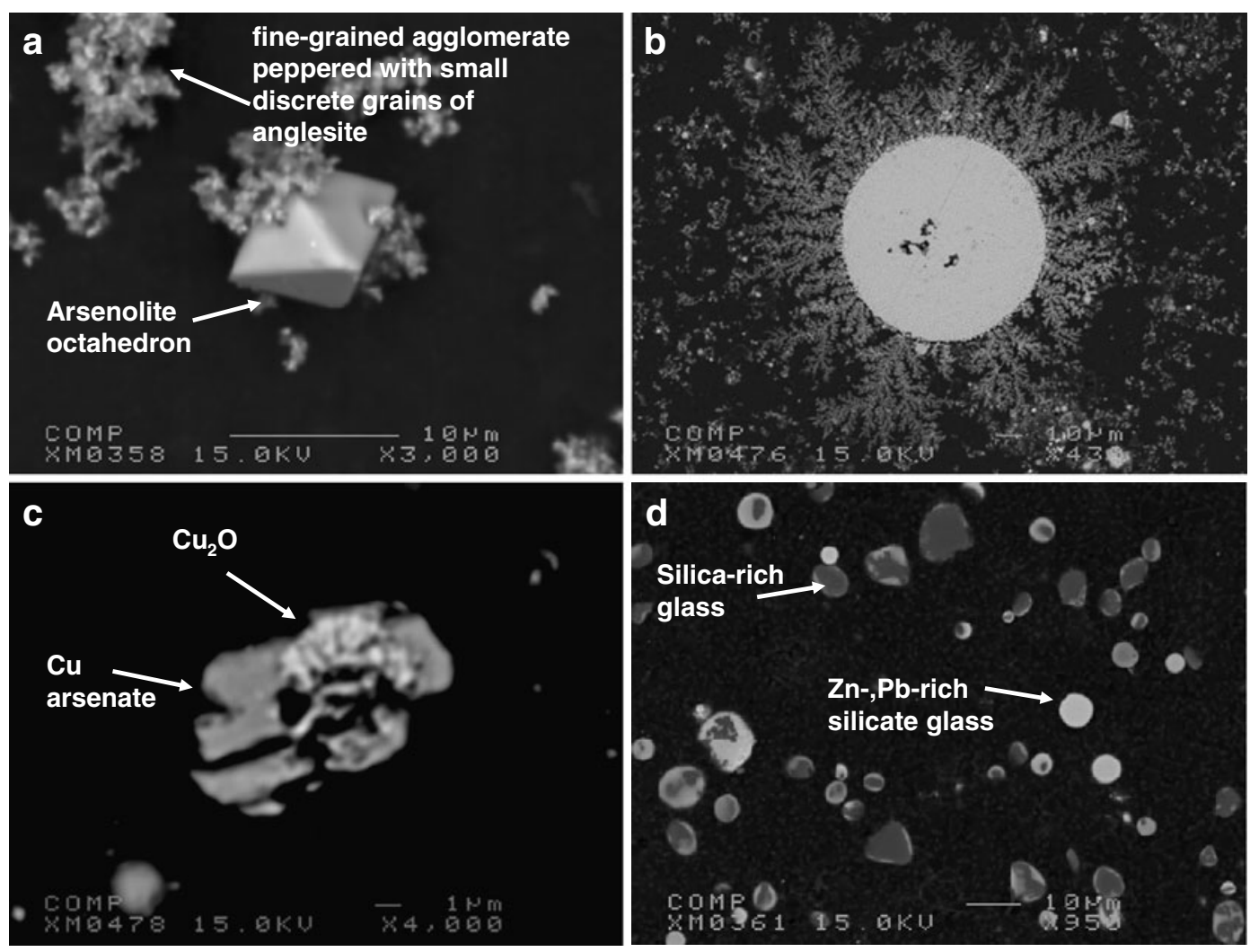

Fig. 5 BSE images of B smelter stack particulates: a euhedral crystal of arsenolite and fine-grained agglomerate laced with small bright grains of anglesite in a grain mount of the a-r material; $\mathbf{b ~} \mathrm{Cu}_{2} \mathrm{~S}$ grain with dendritic overgrowths

in a polished mount of the a-r material; c coexisting $\mathrm{Cu}_{2} \mathrm{O}$ and $\mathrm{Cu}$ arsenate in polished mount of the a-r material; $\mathbf{d}$ glassy silicate spheres of various compositions in a polished mount of the a-r material 


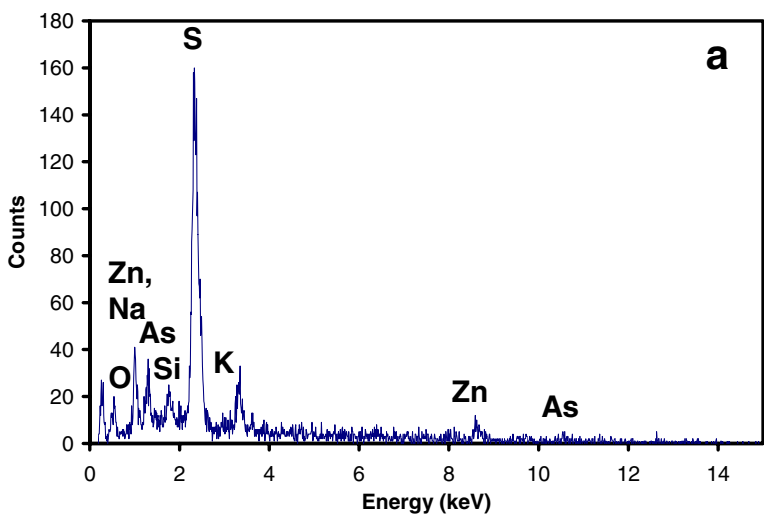

Fig. 6 EDS spectra obtained on grains of the B smelter stack particulates (note that EDS has Be window, so the response is poor for the low energy lines such as $\mathrm{O}$ ):

stoichiometry close to $\left(\mathrm{Cu}_{\mathrm{x}} \mathrm{Zn}_{1-\mathrm{x}}\right)_{3}\left(\mathrm{AsO}_{4}\right)_{2} \cdot 2 \mathrm{H}_{2} \mathrm{O}$, for which $\mathrm{x} \approx 0.98$ and with a minor substitution of As by S (Table 4, Analysis \#4).

It was not possible to obtain definitive identification of a gunningite phase with a simple $\mathrm{ZnSO}_{4} \cdot \mathrm{H}_{2} \mathrm{O}$ composition by SEM/EPMA characterisation. However, $\mathrm{Zn}$ can be found associated with $\mathrm{S}$ and $\mathrm{O}$ in fine-grained agglomerates that likely consist of multiple phases too small to be resolved with the spatial resolution of the instrument (Fig. 5a). EDS analysis obtained on this material revealed $\mathrm{K}$ and $\mathrm{Na}$, with minor amounts of As, and Si associated with Zn, S and O (Fig. 6a).

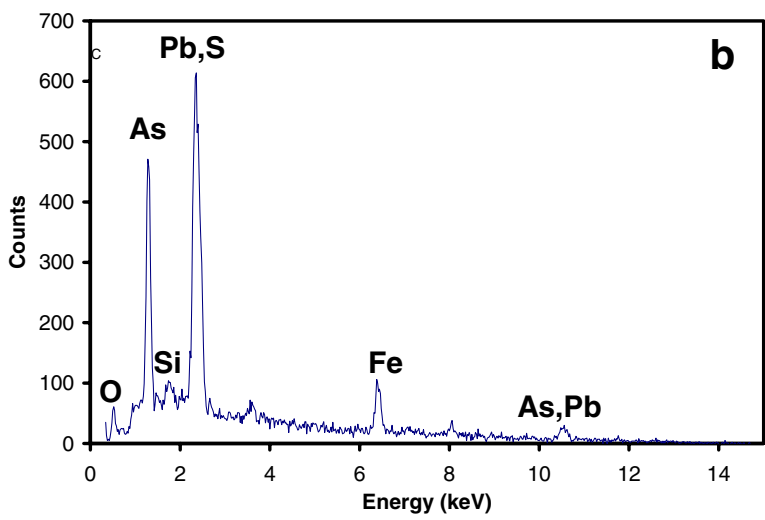

a fine-grained agglomerate shown in Fig. 5a; b residual fine-grained agglomerate after leaching in d.i. water

Thus, as also observed in the A smelter stack sample, there seems to be a strong spatial association between $\mathrm{Zn}$ and the alkalis $\mathrm{Na}$ and $\mathrm{K}$ in the form of fine-grained sulphate compounds, although they may not necessarily all reside in one single phase.

The main amorphous component consists of glassy silicate spheres (Fig. 5d) of variable composition. Quantitative WDS analyses (Table 7) indicate that this glass represents a significant reservoir for $\mathrm{PbO}$ (up to 16.2 wt.\%), $\mathrm{ZnO}$ (up to 30 wt. \%), $\mathrm{Na}_{2} \mathrm{O}$ (up to 1.8 wt. \%), $\mathrm{K}_{2} \mathrm{O}$ (up to 4.5 wt. \%), and $\mathrm{SiO}_{2}$ in the $\mathrm{B}$ particulate sample.

Table 7 Chemical composition of representative B smelter $\mathrm{Zn}-\mathrm{Pb}$-rich glassy silicate spheres

\begin{tabular}{|c|c|c|c|c|c|c|c|c|}
\hline & \multicolumn{6}{|c|}{ Individual analyses } & \multicolumn{2}{|c|}{ Average $(N=15)$} \\
\hline & wt.\% & \pm & wt. \% & \pm & wt.\% & \pm & wt. \% & S.D \\
\hline $\mathrm{SiO}_{2}$ & 45.78 & 0.67 & 52.93 & 0.71 & 49.60 & 0.69 & 44.25 & 8.01 \\
\hline $\mathrm{Al}_{2} \mathrm{O}_{3}$ & 0.29 & 0.09 & 0.15 & 0.08 & 0.70 & 0.11 & 2.89 & 5.39 \\
\hline $\mathrm{FeO}$ & 0.36 & 0.17 & 0.29 & 0.16 & 2.80 & 0.29 & 0.96 & 0.82 \\
\hline $\mathrm{CuO}$ & 7.71 & 0.58 & 12.59 & 0.73 & 6.85 & 0.56 & 8.04 & 2.55 \\
\hline $\mathrm{ZnO}$ & 30.02 & 1.08 & 18.94 & 0.89 & 21.20 & 0.92 & 25.18 & 6.40 \\
\hline $\mathrm{PbO}$ & 10.34 & 1.04 & 9.88 & 1.02 & 13.55 & 1.18 & 11.56 & 3.49 \\
\hline $\mathrm{CaO}$ & 0.04 & 0.07 & 0.04 & 0.07 & 0.09 & 0.07 & 0.09 & 0.10 \\
\hline $\mathrm{Na}_{2} \mathrm{O}$ & 1.35 & 0.20 & 1.35 & 0.23 & 1.46 & 0.23 & 1.15 & 0.36 \\
\hline $\mathrm{K}_{2} \mathrm{O}$ & 2.52 & 0.24 & 3.38 & 0.27 & 2.71 & 0.25 & 2.82 & 0.99 \\
\hline $\mathrm{As}_{2} \mathrm{O}_{5}$ & 0.25 & 0.21 & 0.34 & 0.22 & 0.25 & 0.21 & 2.19 & 3.27 \\
\hline $\mathrm{SO}_{3}$ & 0.11 & 0.10 & 0.14 & 0.11 & 0.03 & 0.12 & 0.18 & 0.19 \\
\hline Total & 98.77 & & 100.03 & & 99.25 & & 99.31 & \\
\hline
\end{tabular}

In addition to three representative individual analyses, the average of 15 analyses and the associated standard deviation $(\mathrm{SD})$ are presented. The uncertainty $( \pm$ ) for the individual analyses represents $3 \sigma$ based on counting statistics 
The crystalline phases identified by XRD in the leach residue of the $\mathrm{B}$ smelter stack particulates in OECD 203 were anglesite and tenorite, $\mathrm{CuO}$. The lack of detected gunningite and arsenolite suggests the high solubility of these phases.

SEM/EPMA was also used to characterise the residue from leaching of the $\mathrm{B}$ smelter stack particulates in d.i. water. Anglesite and the glassy silicate spheres, acting as a refractory reservoir for some of the $\mathrm{Pb}, \mathrm{Zn}$ and alkalis, are both preserved. Finally, EDS analysis suggests that anglesite is sometimes intimately mixed with a $\mathrm{Fe}(+/-$ $\mathrm{Cu}$ ) arsenate, most likely amorphous in nature (Fig. 6b).

Quantitative speciation The step-wise apportioning procedure yields this quantitative speciation for the B smelter stack particulates:

- $20 \% \mathrm{ZnSO}_{4} \cdot \mathrm{H}_{2} \mathrm{O}$ (identified by XRD);

- $20 \% \mathrm{PbSO}_{4}$ (identified by XRD and EDS);
- $12 \% \mathrm{CuSO}_{4}$;

- $8.7 \% \mathrm{As}_{2} \mathrm{O}_{3}$ (identified by XRD and EDS);

- $6.1 \% \mathrm{~K}_{2} \mathrm{SO}_{4}$ (suggested by EDS data);

- $5.2 \% \mathrm{SiO}_{2}$ (in silicate glass spheres, based on WDS data);

- $4.3 \% \mathrm{Na}_{2} \mathrm{SO}_{4}$ (suggested by EDS data);

- $4.1 \%\left(\mathrm{Cu}_{0.98} \mathrm{Zn}_{0.02}\right)_{3}\left(\mathrm{AsO}_{4}\right)_{2} \cdot 2 \mathrm{H}_{2} \mathrm{O}$ (based on WDS data);

- $2.4 \% \mathrm{Fe}_{2} \mathrm{O}_{3}$;

- $1.9 \% \mathrm{CuO}$ (incorporated in silicate glass based on WDS data);

- $\quad 1.8 \% \mathrm{ZnO}$ (incorporated in silicate glass based on WDS data);

- $1.4 \% \mathrm{CaSO}_{4}$.

The minor oxides, $\mathrm{Al}_{2} \mathrm{O}_{3}, \mathrm{CaO}, \mathrm{Fe}_{2} \mathrm{O}_{3}$, and some of the $\mathrm{K}_{2} \mathrm{O}, \mathrm{Na}_{2} \mathrm{O}, \mathrm{PbO}$ and $\mathrm{ZnO}$ are most likely incorporated within the silicate glass which would account for their insoluble percentages. $\mathrm{Sb}_{2} \mathrm{O}_{5}$, $\mathrm{CdO}, \mathrm{Ag}, \mathrm{NiO}, \mathrm{SeO}_{2}$ and $\mathrm{Cr}_{2} \mathrm{O}_{3}$ are calculated

Table 8 Chemical analysis of C smelter stack particulates and distributions of analytes between leachates and residues

\begin{tabular}{|c|c|c|c|c|c|c|c|c|c|c|}
\hline \multirow{2}{*}{\multicolumn{2}{|c|}{$\begin{array}{l}\text { B smelter } \\
\text { as-received }\end{array}$}} & \multicolumn{9}{|l|}{ Leached in } \\
\hline & & \multicolumn{3}{|l|}{ OECD 203} & \multicolumn{3}{|l|}{ d.i. $\mathrm{H}_{2} \mathrm{O}$} & \multicolumn{3}{|l|}{ RICH 95} \\
\hline Analyte & wt. \% & \% Leached & $\begin{array}{l}\% \text { In } \\
\text { residue }\end{array}$ & $\begin{array}{l}\text { Mass } \\
\text { balance, \% }\end{array}$ & \% Leached & $\begin{array}{l}\% \text { In } \\
\text { residue }\end{array}$ & $\begin{array}{l}\text { Mass } \\
\text { balance, \% }\end{array}$ & $\%$ Leached & $\begin{array}{l}\% \text { In } \\
\text { residue }\end{array}$ & $\begin{array}{l}\text { Mass } \\
\text { balance, \% }\end{array}$ \\
\hline As & 17.66 & 47.56 & 57.72 & 105 & 49.28 & 48.52 & 98 & 45.48 & 63.27 & 109 \\
\hline $\mathrm{Cu}$ & 5.68 & 12.8 & 89.2 & 102 & 13.7 & 75.9 & 90 & 11.1 & 103 & 114 \\
\hline $\mathrm{Zn}$ & 17.58 & 80.94 & 37.35 & 118 & 83.10 & 31.01 & 114 & 79.46 & 39.85 & 119 \\
\hline $\mathrm{Ni}$ & 0.0004 & 43 & 33 & 76 & 50 & 28 & 78 & 49 & 113 & 162 \\
\hline $\mathrm{Pb}$ & 8.28 & 0.0180 & 98.4 & 98 & 0.0162 & 88.0 & 88 & 0.0111 & 108.59 & 109 \\
\hline $\mathrm{Cd}$ & 0.603 & 52.3 & 46.3 & 99 & 52.2 & 41.9 & 94 & 46.8 & 56.7 & 104 \\
\hline $\mathrm{Se}$ & 0.0085 & 4.2 & 20 & 24 & 4.2 & 16 & 20 & 4.2 & 21 & 25 \\
\hline $\mathrm{Sb}$ & 0.208 & 2.89 & 114 & 116 & 2.74 & 98.3 & 101 & 2.82 & 120 & 123 \\
\hline $\mathrm{Ag}$ & 0.0063 & 0.21 & 116 & 117 & 0.056 & 107 & 107 & 0.056 & 145 & 145 \\
\hline $\mathrm{Cr}$ & 0.0006 & 0.6 & 62 & 62 & 0.6 & 52 & 52 & 0.6 & 94 & 95 \\
\hline $\mathrm{Fe}$ & 0.829 & 0.0286 & 92.9 & 93 & 0.00157 & 83.1 & 83 & 0.0203 & 108 & 108 \\
\hline $\mathrm{C}$ & 0.025 & & & & & & & & & \\
\hline $\mathrm{Al}$ & 0.0773 & 0.767 & 68.6 & 69 & 0.486 & 54.4 & 55 & 0.788 & 69.5 & 70 \\
\hline $\mathrm{Ca}$ & 0.131 & & & & 40.2 & 24.8 & 65 & 15.0 & 38.8 & 54 \\
\hline $\mathrm{Mg}$ & 0.0096 & & & & 93.7 & 30.4 & 124 & & & \\
\hline $\mathrm{K}$ & 2.25 & 100 & 4.73 & 105 & 99.5 & 4.35 & 104 & 100 & 5.41 & 106 \\
\hline $\mathrm{Na}$ & 0.554 & 101 & 2.73 & 103 & 104 & 2.45 & 106 & 100 & 3.54 & 104 \\
\hline $\mathrm{SO}_{4}$ & 22.36 & 86.17 & 15.71 & 102 & 84.70 & 14.00 & 99 & 87.20 & 16.37 & 104 \\
\hline $\mathrm{Si}$ & 0.196 & & & & & & & & & \\
\hline \multirow[t]{3}{*}{ Total } & 77.35 & \multirow{3}{*}{\multicolumn{2}{|c|}{$\begin{array}{l}\text { Initial wt., g } \\
\text { Residue wt., g } \\
\text { \% Leached }\end{array}$}} & 20.0013 & \multirow{3}{*}{\multicolumn{2}{|c|}{$\begin{array}{l}\text { Initial wt., g } \\
\text { Residue wt., g } \\
\text { \% Leached }\end{array}$}} & 20.0008 & \multicolumn{2}{|c|}{ Initial wt., g } & 20.0013 \\
\hline & & & & 10.5480 & & & 8.8298 & Residue wt., & & 11.2819 \\
\hline & & & & 47 & & & 56 & \% Leached & & 44 \\
\hline \multicolumn{2}{|c|}{ Initial $\mathrm{pH}$} & \multicolumn{3}{|l|}{7.95} & \multicolumn{3}{|c|}{4.76} & \multicolumn{3}{|c|}{7.88} \\
\hline \multicolumn{2}{|c|}{ Final pH } & \multicolumn{3}{|l|}{4.16} & \multicolumn{3}{|l|}{4.14} & \multicolumn{3}{|l|}{4.23} \\
\hline
\end{tabular}


to be less than about $0.5 \%$ each. The sum of the calculated totals at $90 \%$ (Table 5) is somewhat low, partly related to uncertainty in the phase compositions of some of the fine-grained material, but nonetheless a good indication of the quantitative speciation of the B smelter stack particulates.
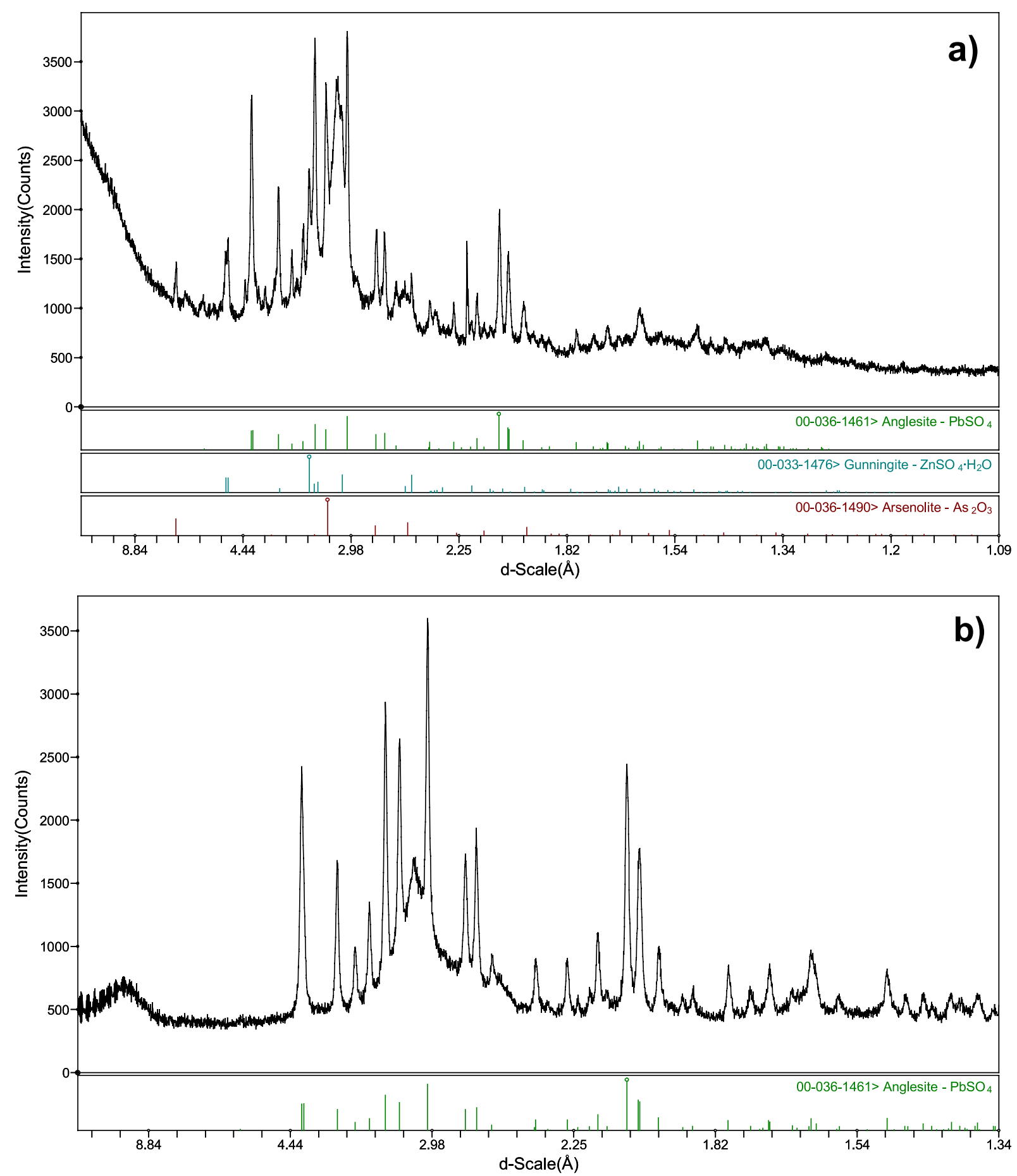

Fig. 7 XRD patterns of a the a-r $\mathbf{C}$ smelter stack particulates and $\mathbf{b}$ the residue from leaching a-r C smelter stack particulates in OECD 203 

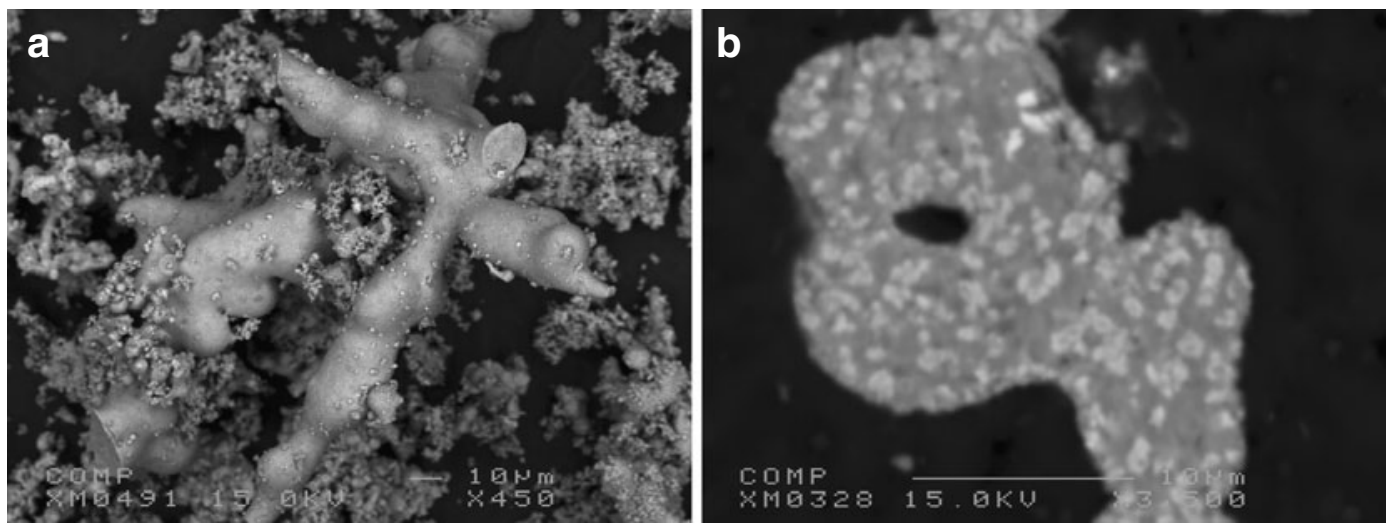

Fig. 8 BSE images of C smelter stack particulates: a arborescent structure in grain mount of a-r material; $\mathbf{b}$ cross-section of a branch of arborescent structure in a polished mount of the a-r material suggesting the presence of at least two phases
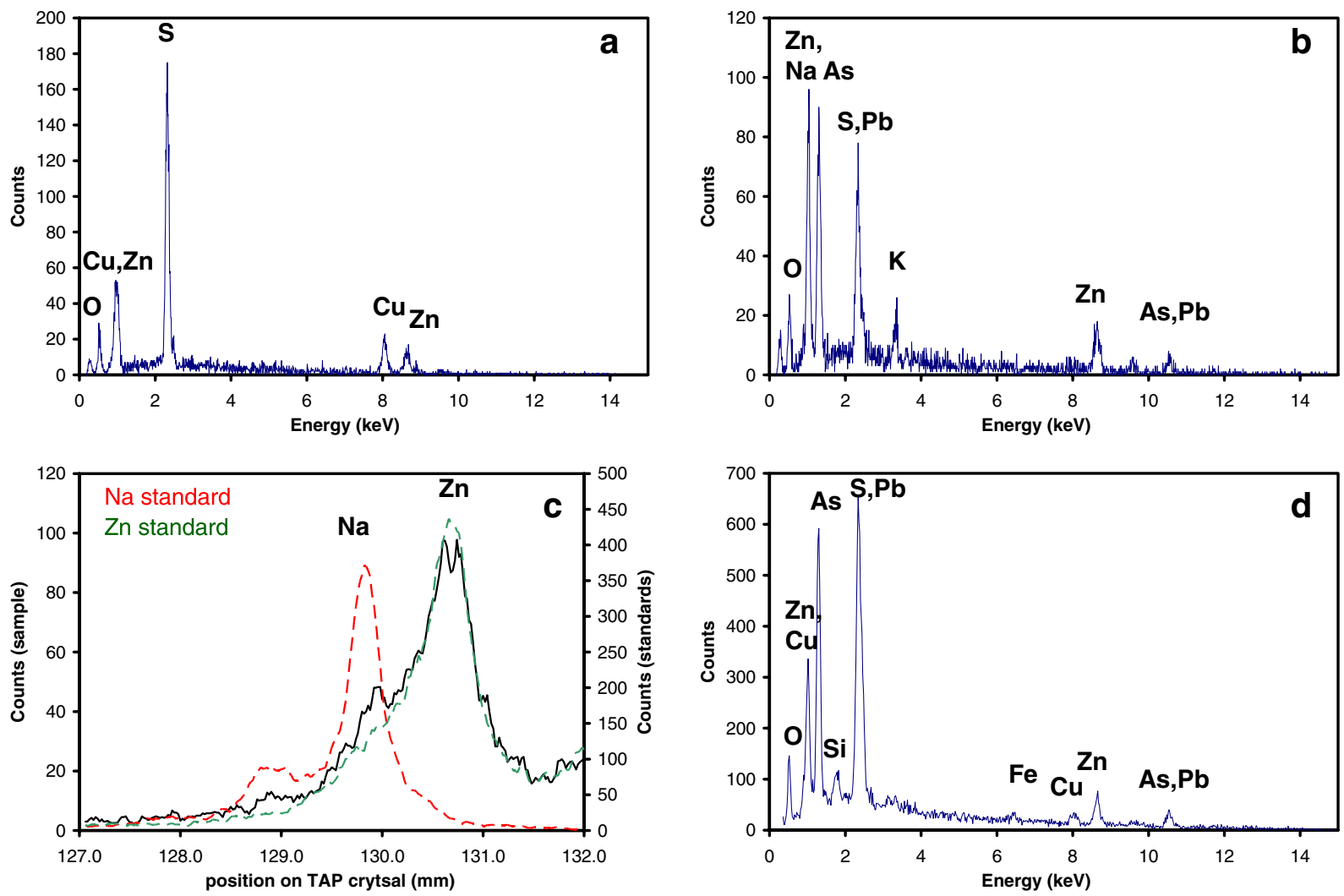

Fig. 9 EDS spectra obtained on grains from the C smelter stack particulates (note EDS has Be window, so the response is poor for the low energy lines such as $\mathrm{O}$ ): $\mathbf{a} \mathrm{Cu}-$ Zn sulphate; b arborescent structure shown in Fig. 8a, b; c WDS spectrum in the energy region for $\mathrm{Na} \mathrm{K} \alpha$ and $\mathrm{Zn} \mathrm{L} \alpha$

obtained with a TAP diffracting crystal for the arborescent structure shown in Fig. 8a confirming the presence of $\mathrm{Na}$; d preserved arborescent structure in residue after leaching in d.i. water 
In aquatic media, the gunningite, $\mathrm{CuSO}_{4}$, $\mathrm{K}_{2} \mathrm{SO}_{4}, \mathrm{Na}_{2} \mathrm{SO}_{4}$ and most of the arsenolite should be soluble, whereas anglesite, copper sulphide, copper oxide, $\mathrm{Cu}-\mathrm{Zn}$ arsenate and silicate glass would be insoluble.

\section{C smelter}

Chemical composition of a-r particulates The bulk chemical analyses of the a-r $\mathrm{C}$ smelter particulates are presented in Table 8. In comparison with the $\mathrm{A}$ and $\mathrm{B}$ particulate samples, the $\mathrm{C}$ material has significantly greater levels of $\mathrm{As}$ and $\mathrm{Zn}$, $17.6 \%$ each, and a lesser amount of $\mathrm{SO}_{4}, 22.4 \%$. $\mathrm{Cu}$ and $\mathrm{Pb}$ represent $5.7 \%$ and $8.3 \%$ respectively. The minor analytes $\mathrm{Ni}, \mathrm{Cr} \mathrm{Ag}, \mathrm{Se}, \mathrm{Mg}, \mathrm{C}, \mathrm{Ca}, \mathrm{Si}$, $\mathrm{Sb}, \mathrm{Cd}, \mathrm{Al}, \mathrm{Fe}, \mathrm{Na}$ and $\mathrm{K}$ occurred in the range $0.0004 \%$ to $2.25 \%$.

Leaching results and mass balances The distributions of the analytes between the leachates and residues, as well as the mass balances for each analyte are also shown in Table 8 . With values in the range $88 \%$ to $119 \%$, the mass balance data for all three leaching media reveal that the components $\mathrm{As}, \mathrm{Cu}, \mathrm{Pb}, \mathrm{SO}_{4}$ and $\mathrm{Zn}$ are acceptably well-accounted for. The data of Table 8 also reveal that $\mathrm{As}, \mathrm{Cd}, \mathrm{Cu}, \mathrm{SO}_{4}$ and $\mathrm{Zn}$ dissolved to the extent of about $47 \%, 50 \%, 13 \%, 86 \%$ and $81 \%$, respectively, while the dissolution of $\mathrm{Pb}$ was about $0.02 \%$. The weight percentages of the samples leached over the $6 \mathrm{hr}$ were 47, 56 and 44 for the OECD 203, d.i. water and RICH-95 lixiviants, respectively.

Of the minor components, the mass balances for $\mathrm{Cd}, \mathrm{Fe}, \mathrm{K}_{2} \mathrm{O}, \mathrm{Na}_{2} \mathrm{O}$ and $\mathrm{Sb}$ lie in the range 83$123 \%$ and are also reasonable. However, those for $\mathrm{Al}_{2} \mathrm{O}_{3}$ and the trace elements $\mathrm{Cr}$ and Se suggest significant quantities for which we cannot calculate a reasonable distribution between leachate and residue. This result is not unexpected owing to their relatively low concentrations in the original sample, the leachates and the residues.

Mineralogical analyses Gunningite, anglesite and arsenolite are major crystalline phases identified by XRD, Fig. 7a. However, with the available databases, we could not identify one of the major peaks corresponding to a d-spacing of $3.11 \AA$.
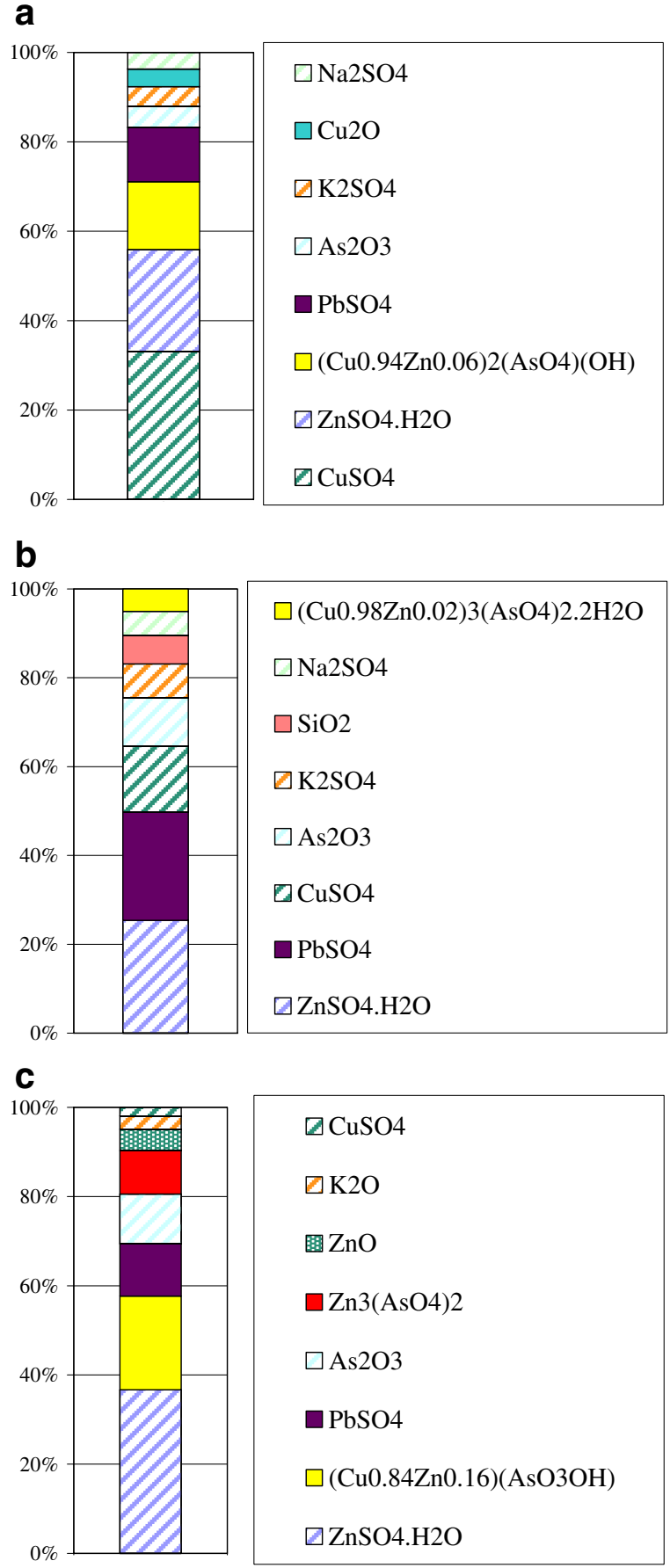

Fig. 10 Comparison of calculated compositions of smelter stack particulates. Commonalities and differences are discussed in the text. Note that, to enable this comparison, the percentages have been normalised to a $100 \%$ mass balance. Soluble and insoluble compounds are coded with crosshatched and solid bars, respectively. In the case of $\mathrm{ZnO}$ for smelter C, about $50 \%$ is soluble 
Once again, the background profile suggests the presence of a significant amount of amorphous material.

In addition to anglesite and arsenolite, a $(\mathrm{Cu}$, $\mathrm{Zn}$ ) arsenate was also identified by SEM/EPMA. Based on WDS analyses (e.g. Table 4, analysis \#5), some of the grains exhibit a stoichiometry close to $\left(\mathrm{Cu}_{0.84} \mathrm{Zn}_{0.16}\right)\left(\mathrm{AsO}_{3} \mathrm{OH}\right)$ with minor $\mathrm{S}$ substituting for As. It was not possible to isolate a pure hydrated zinc sulphate, gunningite. Nonetheless, a $(\mathrm{Cu}, \mathrm{Zn})$ sulphate is commonly observed, Fig. 9a.

Arborescent structures, Fig. 8a, that consist of at least two phases, Fig. 8b, are abundant. Although they could not be completely spatially resolved during EDS analysis, they appear to consist of a $\mathrm{Pb}-, \mathrm{S}-, \mathrm{O}$-rich phase, most likely anglesite, and of a (Na,K)-bearing $\mathrm{Zn}$ arsenate (Fig. 9b, c). Considering the abundance of this material, this zinc arsenate may well represent the unidentified crystalline phase from the XRD.

In the XRD pattern of the residue from the OECD 203 leaching of the C smelter stack particulates (Fig. 7b), the only crystalline phase that could be identified was anglesite. However, the unidentified peak at $\mathrm{d}=3.11 \AA$ observed in the a-r sample is still present and could be zinc arsenate.

SEM/EPMA characterisation of a residue from leaching of the $\mathrm{C}$ smelter stack particulates in d.i. water clearly confirmed anglesite and copper arsenate as insoluble phases. Moreover, the characteristic arborescent structure is also preserved. EDS analyses suggest that it is a zinc arsenate of composition comparable to that in the a-r sample, with much lower levels of alkalis, Fig. 9d.

Quantitative speciation From the above data, the quantitative speciation calculated for the $\mathrm{C}$ smelter stack particulates is:

- $34 \% \mathrm{ZnSO}_{4} \cdot \mathrm{H}_{2} \mathrm{O}$ (gunningite);

- $19 \% \quad\left(\mathrm{Cu}_{0.84} \mathrm{Zn}_{0.16}\right)\left(\mathrm{AsO}_{3} \mathrm{OH}\right)$ (based on WDS data);

- $11 \% \mathrm{PbSO}_{4}$ (anglesite);

- $10 \% \mathrm{As}_{2} \mathrm{O}_{3}$ (arsenolite)

- $9.0 \% \quad \mathrm{Zn}_{3}\left(\mathrm{AsO}_{4}\right)_{2}$ (assumed composition based on EDS data)

- $4.4 \% \mathrm{ZnO}$;
- $2.8 \% \mathrm{~K}_{2} \mathrm{O}$ (possibly associated with $\mathrm{Zn}$ in an arsenate phase, based on EDS data);

- $1.8 \% \mathrm{CuSO}_{4}$;

and about $1 \%$ or less of each of $\mathrm{Fe}_{2} \mathrm{O}_{3}, \mathrm{Na}_{2} \mathrm{O}$, $\mathrm{PbO}, \mathrm{CdO}, \mathrm{SiO}_{2}, \mathrm{Sb}_{2} \mathrm{O}_{5}, \mathrm{CaO}, \mathrm{Al}_{2} \mathrm{O}_{3}, \mathrm{C}, \mathrm{Ag}$, $\mathrm{MgO}, \mathrm{SeO}_{2}, \mathrm{Cr}_{2} \mathrm{O}_{3}$ and $\mathrm{NiO}$. The total of the calculated percentages of the components accounts for a quite reasonable $97 \%$ by weight of the a-r C smelter stack particulates, Table 5.

Gunningite, $\mathrm{CuSO}_{4}$, and arsenolite appear soluble in the lixiviants, whereas the $\mathrm{Cu}$ and $\mathrm{Zn}$ arsenates and anglesite are preserved in the residue.

\section{Conclusions}

In examining particulates from three base metal smelter stacks as potential sources of metals released to the atmosphere, we observed in all samples rather complex phase assemblages with the presence of sulphates, arsenates and silicates whose abundances and compositions are strongly influenced by the bulk chemistry. Such distinct speciation will have important implications for the environment in terms of the distribution of some critical elements, such as As, between residue and solution during contact with aqueous media. As illustrated in Fig. 10, there were commonalities in composition among all three smelter stack particulates, which contained significant quantitiesin the range $20-34 \%$ - of $\mathrm{ZnSO}_{4} \cdot \mathrm{H}_{2} \mathrm{O}$, although the $\mathrm{C}$ smelter particulates were the richest in this among all three. Again, the B particulates were the richest in insoluble $\mathrm{PbSO}_{4}$ at $20 \%$, compared to $\sim 11 \%$ for the $\mathrm{A}$ and $\mathrm{C}$ particulates. For $\mathrm{As}_{2} \mathrm{O}_{3}$, most of which was soluble, the $\mathrm{B}$ and $\mathrm{C}$ particulates contained similar $9-10 \%$ levels, while the A particulates were about $4 \%$. All three samples contained insoluble $\mathrm{Cu}-\mathrm{Zn}$ arsenates in the order C $(19 \%)>A(13 \%)>B(4 \%)$, while the C sample also contained $9 \% \mathrm{Zn}_{3}\left(\mathrm{AsO}_{4}\right)_{2}$ for a total of $28 \%$ arsenates. At $29 \%$, the A smelter particulates contained by far the greatest amount of the readily soluble $\mathrm{CuSO}_{4}$, with the $\mathrm{B}$ and $\mathrm{C}$ samples containing $12 \%$ and only $2 \%$, respectively.

Thus in general, the fate of $\mathrm{Cu}$ and $\mathrm{Zn}$ as sulphates and $\mathrm{As}_{2} \mathrm{O}_{3}$ in these smelter particulates would be dissolution and bioavailability in the 
aquatic environment, while the arsenates and $\mathrm{Pb}$ as $\mathrm{PbSO}_{4}$, which are relatively insoluble, would tend to be stable in aquatic media, soil or sediments. The data and approach may be useful in estimating water-soil-sediment partitioning and the environmental effects of the releases of these and other smelter stack particulates as well as in deriving site-specific risk assessments in general, including predictions of the behaviour of particulates released to the atmosphere, for these and other operations.

Acknowledgements The authors are grateful to John Wilson and Derek Smith for XRD analyses, and to CANMET-MMSL's Analytical Services Group for the bulk chemical analyses. This work was supported by Natural Resources Canada.

Open Access This article is distributed under the terms of the Creative Commons Attribution Noncommercial License which permits any noncommercial use, distribution, and reproduction in any medium, provided the original author(s) and source are credited.

\section{Appendix 1}

Overview of analytical methods

In Table 9 of Appendix 1, we have listed the methods used to determine the percentages or concen- trations of each analyte in each solid or solution. For the solid samples, CANMET-MMSL's Analytical Services Group (ASG) used four different methods of solids digestion followed by analysis of the resulting solutions. For $\mathrm{Ag}, \mathrm{Al}, \mathrm{As}, \mathrm{Pb}, \mathrm{Sb}$, $\mathrm{Se}$ and $\mathrm{Si}$ in the a-r samples and for $\mathrm{As}$ and $\mathrm{Sb}$ in the residues, they used digestion in an aqua regia matrix in a sealed vessel within a CEM Microwave Digestion System Model MDS-81d, and then with appropriate dilution, analysed the resulting solutions using a Varian Vista RL ICP-AES. For Cd, $\mathrm{Cr}, \mathrm{Cu}, \mathrm{Fe}, \mathrm{K}, \mathrm{Mg}, \mathrm{Na}, \mathrm{Ni}$ and $\mathrm{Zn}$ in the a-r samples and for $\mathrm{Ag}, \mathrm{Al}, \mathrm{Ca}, \mathrm{Cd}, \mathrm{Cr}, \mathrm{Cu}, \mathrm{Fe}, \mathrm{K}$, $\mathrm{Mg}, \mathrm{Na}, \mathrm{Ni}, \mathrm{Pb}, \mathrm{Se}$ and $\mathrm{Zn}$ in the residues, they dissolved the samples in an $\mathrm{HCl}, \mathrm{HNO}_{3}, \mathrm{HClO}_{4}$ and $\mathrm{HF}$ matrix, then evaporated the solution to a paste and dissolved it in dilute $\mathrm{HNO}_{3}$, which they then analysed by ICP-AES. For $\mathrm{Ca}$ in the residues, they used fusion with $\mathrm{LiBO}_{2}$ and then ICP-EAS analysis of the dissolved fusion product. For $\mathrm{SO}_{4}$ in the a-r samples and in the residues, they dissolved the sulphate in a sodium carbonate solution and determined the dissolved $\mathrm{SO}_{4}$ on a Dionex HPLC (high pressure liquid chromatograph). For $S$ in the a-r samples, they used LECO furnace analysis.

For leach solution samples, they ran them undiluted or diluted by a factor of 10 and used

Table 9 Analytical methods and LOQs

\begin{tabular}{|c|c|c|c|c|c|c|c|c|c|c|c|c|c|c|c|c|c|c|}
\hline & $\mathrm{Ag}$ & $\mathrm{Al}$ & As & $\mathrm{Ca}$ & $\mathrm{Cd}$ & $\mathrm{Cr}$ & $\mathrm{Cu}$ & $\mathrm{Fe}$ & $\mathrm{K}$ & $\mathrm{Mg}$ & $\mathrm{Na}$ & $\mathrm{Ni}$ & $\mathrm{Pb}$ & $\mathrm{SO}_{4}$ & $\mathrm{Sb}$ & $\mathrm{Se}$ & $\mathrm{Si}$ & $\mathrm{Zn}$ \\
\hline $\begin{array}{l}\text { Method for a-r } \\
\text { particulates }\end{array}$ & 1,5 & 1,5 & 1,5 & 2,5 & 3,5 & 3,5 & 3,5 & 3,5 & 3,5 & 3,5 & 3,5 & 3,5 & 1,5 & 4,6 & 1,5 & 1,5 & 1,5 & 3,5 \\
\hline ICP-AES LOQ, $\mu \mathrm{g} / \mathrm{L}$ & 0.8 & 7.9 & 40 & 1.3 & 1.5 & 2.6 & 3.9 & 1.8 & 143 & 0.1 & 4.2 & 7 & 30 & & 42 & 176 & 5.7 & 6.6 \\
\hline $\begin{array}{l}{\left[\mathrm{Me}_{\min } .\right] / \mathrm{LOQ}} \\
\mathrm{HPLC} \mathrm{LOQ}, \mu \mathrm{g} / \mathrm{L} \\
{\left[\mathrm{SO}_{4 \mathrm{~min} .}\right] / \mathrm{LOQ}}\end{array}$ & 286 & 1.1 & 2000 & 147 & 5800 & 7 & 367 & 113 & 314 & 329 & 3313 & 1.6 & 25 & $\begin{array}{l}200 \\
3370\end{array}$ & 38 & 0.2 & 7.6 & 246 \\
\hline Method for residues & 3,5 & 3,5 & 1,5 & 3,5 & 3,5 & 3,5 & 3,5 & 3,5 & 3,5 & 3,5 & 3,5 & 3,5 & 3,5 & 4,6 & 1,5 & 3,5 & & 3,5 \\
\hline ICP-AES LOQ, $\mu \mathrm{g} / \mathrm{L}$ & 0.8 & 3.4 & 86 & 11 & 2 & 1.9 & 1.6 & 0.9 & 5.8 & 16 & 52 & 12 & 33 & & 37 & 159 & & 16 \\
\hline $\begin{array}{l}{\left[\mathrm{Me}_{\min } .\right] / \mathrm{LOQ}} \\
\mathrm{HPLC} \mathrm{LOQ}, \mu \mathrm{g} / \mathrm{L} \\
{\left[\mathrm{Me}_{\min .}\right] / \mathrm{LOQ}}\end{array}$ & 504 & 705 & 21 & 189 & 679 & 10 & 1070 & 4056 & 880 & 11 & 14 & 1.0 & 118 & $\begin{array}{l}200 \\
1460\end{array}$ & 36 & 1.1 & & 28 \\
\hline $\begin{array}{l}\text { Method for leach } \\
\text { solutions }\end{array}$ & 5 & 5 & 5 & 5 & 5 & 5 & 5 & 5 & 5 & 5 & 5 & 5 & 5 & 7 & 5 & 5 & 5 & 5 \\
\hline ICP-AES LOQ, $\mu \mathrm{g} / \mathrm{L}$ & 0.7 & 4 & 20 & 4.1 & 1.7 & 0.7 & 1.4 & 2 & 14 & 15 & 47 & 13 & 32 & & 21 & 72 & & 7 \\
\hline $\begin{array}{l}{\left[\mathrm{Me}_{\min } .\right] / \mathrm{LOQ}} \\
\mathrm{HPLC} \mathrm{LOQ}, \mu \mathrm{g} / \mathrm{L} \\
{\left[\mathrm{Me}_{\min .}\right] / \mathrm{LOQ}}\end{array}$ & 1.8 & 9.3 & 930 & 126 & 1865 & 6 & 4700 & 6 & 643 & 62 & 117 & 8 & 1.4 & $\begin{array}{l}200 \\
8460\end{array}$ & 16 & & & 3575 \\
\hline
\end{tabular}

1 microwave leaching, 2 metaborate fusion, 3 four-acid dissolution, 4 carbonate leaching, 5 ICP-AES, 6 HPLC for carbonate solutions, 7 HPLC 
ICP-AES for all analytes except $\mathrm{SO}_{4}$, for which they used the Dionex HPLC.

Throughout, they used reagent grade chemicals, trace metal grade acids and $18 \mathrm{M} \Omega$ deionised water. Operating under Certificate No. 004638, our ASG is in compliance with ISO 9002.

For each set of ICP-AES analyses, our ASG incorporated several $\mathrm{QA} / \mathrm{QC}$ measures to verify initial instrument calibration and to monitor instrument stability. For every 10 samples, they analysed at least one duplicate sample, and for every 10 samples, they analysed one mid-range standard to check the stability of the ICP-AES instrumentation. After the initial calibration, they determined the LOQs by multiplying by 10 the average of the standard deviations of five measured calibration blanks. Typically, for the analyses of microwave digestion solutions of $\sim 0.1 \mathrm{~g}$ of each of the three a-r smelter particulates plus one duplicate, they would run these undiluted and at 10 and 100 times dilution on the ICP-AES. In the same batch, preceding and interspersed among the digestion solutions, they would run five determinations of LOQ; between five (e.g., for minor elements such as $\mathrm{Se}$ ) and 13 (e.g., for major elements such as $\mathrm{Pb}$ ) multi-component standards comprising solid and solution Certified Reference Materials (CRMs) and spiked multi-component solutions; one $2 \% \mathrm{HNO}_{3}$ blank; and 10 rinses. They used a similar approach for the four-acid digestion solutions of $\sim 0.25 \mathrm{~g}$ of both the a-r particulates and the leach residues, with as many as 17 solid and liquid standards for $\mathrm{Cu}$ in the a-r particulates and as few as five for $\mathrm{Se}$ in the residues.

\section{LOQs}

As with all ICP-AES instruments, the LOQs varied according to matrix and analyte. As per Table 9, for the major analytes $\mathrm{As}, \mathrm{Cu}, \mathrm{Pb}, \mathrm{SO}_{4}$ and $\mathrm{Zn}$ in the a-r particulates, the LOQs were $40,3.9,30,200$ and $6.5 \mu \mathrm{g} / \mathrm{L}$, respectively. Also in Table 9, these LOQs were as low as 25 (for $\mathrm{Pb}$ ), and as high as 3370 (for $\mathrm{SO}_{4}$ ), times less than the lowest corresponding analyte concentrations in the digestion solutions. For the minor and trace elements, the LOQs varied between $0.1 \mu \mathrm{g} / \mathrm{L}$ (for $\mathrm{Mg}$ ) and $176 \mu \mathrm{g} / \mathrm{L}$ (for Se), and were as low as 1.1 (for $\mathrm{Al}$ ) and as high as 5800 (for $\mathrm{Cd}$ ) times less than the lowest corresponding analyte concentrations in the digestion solutions, Se having been reported as below the LOQ.

For the major analytes $\mathrm{As}, \mathrm{Cu}, \mathrm{Pb}, \mathrm{SO}_{4}$ and $\mathrm{Zn}$ in the residues, the LOQs were 86, 1.6, 33, 200 and $16 \mu \mathrm{g} / \mathrm{L}$, respectively, and were as low as 21 (for As), and as high as 1,460 times (for $\mathrm{SO}_{4}$ ), less than the lowest corresponding analyte concentrations in the digestion solutions. For the minor and trace elements, the minimum and maximum LOQs were 0.8 and $159 \mu \mathrm{g} / \mathrm{L}$, for $\mathrm{Ag}$ and $\mathrm{Se}$, respectively. The LOQ for Ni was close to the lowest measured concentration in the digestion solution, but about 4,000 times less than the corresponding concentration for $\mathrm{Fe}$.

The LOQs for $\mathrm{As}, \mathrm{Cu}, \mathrm{Pb}, \mathrm{SO}_{4}$ and $\mathrm{Zn}$ in the leach solutions were 20, 1.4, 32, 200 and $7 \mu \mathrm{g} / \mathrm{L}$, respectively, and were between 1.4 (for $\mathrm{Pb}$ ) and 8,460 (for $\mathrm{SO}_{4}$ ) times less than the lowest corresponding analyte concentrations. The LOQs for the minor and trace elements lay between 0.7 (for $\mathrm{Ag}$ and $\mathrm{Cr}$ ) and 72 (for $\mathrm{Se}$ ) $\mu \mathrm{g} / \mathrm{L}$, and were between two (for $\mathrm{Ag}$ ) and about 1,900 times (for $\mathrm{Cd}$ ) less than the measured minimum concentrations.

The values of the LOQs for the major analytes were thus low enough to support the following estimates of uncertainties. When, as for some of the minor and trace analytes, the measured concentrations may be close to the LOQs, then the uncertainties will be greater.

Estimates of uncertainties in analyses

\section{Solids}

For analytes determined by digestion-ICP-AES, our ASG reported percentages in a-r solids and leach residues derived from dilutions (none at all, 10 or 100) of both microwave and four-acid digestion solutions in sequences in which the measured values for the standards and spikes best matched the known or certified values within a few percentage points. For instance, for $\mathrm{Pb}$ in the a-r samples, the concentrations of six solution standards lay in the range $99-102 \%$ of the known and certified values, and the measured values for a solid CRM fell in the $93-104 \%$ range of the standard $1.32 \%$ $\mathrm{Pb}$ (i.e., 1.24-1.37\%). Then, the $\mathrm{Pb}$ concentrations 
in the microwave digestion solutions at 100 times dilution for the solid CRM and for the a-r smelter samples lay in the range $0.148-1.407 \mathrm{mg} / \mathrm{L}$, and for the solid CRM, the measured value of $1.37 \%$ $\mathrm{Pb}$ was $104 \%$ of the $1.32 \% \mathrm{~Pb}$ standard. For the duplicate samples of the a-r B smelter particulates, ASG found $\mathrm{Pb}$ values of $13.95 \%$ and $13.97 \%$, for an average of $13.96 \% \pm 0.01 \%$. For the leach residues, ASG obtained $97 \%$ of the $\mathrm{Pb}$ in a solid CRM, and the duplicate analyses of the C smelter water leach residues were $16.50 \%$ and $17.18 \%$ for an average of $16.84 \% \pm 0.02 \%$. Taking the agreement between the measured and certified $\mathrm{Pb}$ values in the CRMs and the close agreement between the two sets of duplicate samples, we estimate that the c.r.u. in the concentration of $\mathrm{Pb}$ for the a-r particulates and the residues to be about $2 \%$.

Using a similar approach for $\mathrm{Cu}$ in the a-r particulates, ASG found values of $7.63 \%$ and $8.12 \%$ $\mathrm{Cu}$ in the duplicate samples, i.e., within less than $1 \%$ of each other, for an average of $7.88 \% \pm$ $0.04 \%$. Moreover, their measured percentage $\mathrm{Cu}$ in a CRM was $100 \%$ of the certified value. The duplicates in the $\mathrm{C}$ smelter water-leach residues were $9.77 \%$ and $10.27 \%$ for an average of $10.02 \% \pm$ $0.02 \%$. Thus for $\mathrm{Cu}$, we would estimate the c.r.u. to be about $1 \%$ in both the a-r particulates and the leach residues.

For As in the a-r particulates, the agreement between the nine measured and known solid and solution standards and spikes was $100.5 \%(\sigma=$ $6.6 \% ; n=9)$. On the other hand, the values for the duplicate samples of the a-r B smelter particulates were $7.92 \%$ and $8.06 \%$, and within less than $1 \%$ of each other for an average of $7.99 \%$. Moreover, the values of As in the duplicates of the $\mathrm{C}$ smelter residues from leaching in the RICH-95 medium were $19.81 \%$ and $19.65 \%$, and also within less than $1 \%$ of each other. So we estimate the c.r.u. in As to be about $2 \%$ in both the a-r particulates and the leach residues.

For $\mathrm{Zn}$ in the a-r particulates, ASG's measured percentage $\mathrm{Zn}$ in a CRM was $98 \%$ of the certified value, and the duplicates for the $\mathrm{C}$ smelter particulates were $17.51 \%$ and $17.65 \%$, yielding an average of $17.58 \% \pm 0.07 \%$. The values of $\mathrm{Zn}$ in the duplicate $\mathrm{C}$ smelter water-leach residues were $12.35 \%$ and $12.07 \%$ for an average of $12.21 \% \pm$
$0.14 \%$. For $\mathrm{Zn}$, we would then estimate the c.r.u. to be about $1 \%$ in both the a-r particulates and the leach residues.

For the minor analytes $\mathrm{Ag}, \mathrm{Al}, \mathrm{Ca}, \mathrm{Cd}, \mathrm{Cr}, \mathrm{Fe}$, $\mathrm{K}, \mathrm{Mg}, \mathrm{Na}, \mathrm{Ni}, \mathrm{Sb}$ and $\mathrm{Se}$, we estimate the relative uncertainties to be about $3 \%$ or less in both the a-r particulates and the leach residues.

For sulphate in the a-r particulates, the agreement between 10 measured and known solid and solution standards and spikes was 98.9\% ( $\sigma=$ $6.8 \% ; \mathrm{n}=10)$. The determinations of sulphate in duplicate samples of the a-r A smelter particulates were $34.41 \%$ and $35.01 \%$ for an average of $35.71 \% \pm 0.30 \%$. So we would estimate the c.r.u. to be $3 \%$ or less. For the leach residues, the agreement between nine measured and known solid and solution standards and spikes was $100.1 \%$ $(\sigma=3.0 ; n=9)$, and duplicate samples resulted in $14.55 \%$ and $14.51 \%$ and an average of $14.53 \% \pm$ $0.02 \%$. Here, we would estimate the c.r.u. to be $2 \%$ or less.

\section{Leach solutions}

Our ASG used similar QA/QC methodology for the leach solutions determined by ICP-AES, which they ran both undiluted and diluted by a factor of 10. They used between four (e.g., for minor analytes such as Se) and seven (e.g., for major analytes such as $\mathrm{Cu}$ ) standards comprising solution CRMs and spiked multi-component solutions. In the case of As, they used seven spikes and CRMs, which yielded $96.9 \%(\sigma=2 \% ; n=7)$ agreement between the measured and known values. For the major metal analytes $\mathrm{As}, \mathrm{Cu}, \mathrm{Pb}$ and $\mathrm{Zn}$, the average percentage agreement between the measured and known values was $98.2 \%$ ( $\sigma=$ $1.7 \% ; n=4)$, and the minimum and maximum percentages were $92 \%$ and $105 \%$. For the remaining 12 analytes, the average percentage agreement between the measured and known values was $100.4 \%(\sigma=1.3 \% ; n=12)$, with the minimum and maximum percentages of $90 \%$ and $116 \%$. Thus, we would estimate the c.r.u. in the solution determinations to be $2 \%$ or less.

For sulphate determinations, our ASG ran 12 standards and spikes, which yielded 101.0\% ( $\sigma=$ $1.7 \% ; n=12$ ) agreement between the measured and known concentrations. So we would estimate 
the c.r.u. in the solution sulphate concentrations to be $2 \%$ or less.

Estimates of uncertainties in quantitative speciation

To estimate the uncertainties in the quantitative speciation of the a-r particulates, we have tabulated the estimated c.r.u. percentages for the analytes in the a-r particulates, residues and leachates, as well as their totals across the three media, in Table 10. For instance, the c.r.u. percentages for As in the a-r particulates, residues and leachates are 2, 2 and 2, respectively, for a total of $6 \%$. To estimate the uncertainty in the percentage of a particular compound, we used the equation

c.r.u. = calculated average wt $\%$

$$
\times\left[(\text { c.r.u. })_{i}+(\text { c.r.u. })_{j}+\text { stdev }\right] / 100
$$

in which (c.r.u.) $)_{\mathrm{i}}$ and (c.r.u $)_{\mathrm{j}}$ are the c.r.u. values for components $\mathrm{i}$ and $\mathrm{j}$ in the compound and stdev is the standard deviation in the calculated average wt. \% from leaching in the three media. As an example, the c.r.u. for $\mathrm{ZnSO}_{4} \cdot \mathrm{H}_{2} \mathrm{O}$ in the $\mathrm{C}$ smelter particulates would be

$34 \times[4+6+1] / 100=4$

so that the calculated average wt.\% for $\mathrm{ZnSO}_{4} \cdot \mathrm{H}_{2} \mathrm{O}$ in the $\mathrm{C}$ smelter particulates lies between $30 \%$ and $38 \%$. Similarly, that for $\mathrm{PbSO}_{4}$ the A smelter particulates would lie between $10 \%$ and $12 \%$. The c.r.u. for a compound with only one component analyte would be relatively

Table 10 Estimated combined relative uncertainties in the concentrations of major, minor and trace analytes

\begin{tabular}{lllll}
\hline Analyte & \multicolumn{2}{l}{$\begin{array}{l}\text { Estimated combined relative } \\
\text { uncertainty (c.r.u.), \%, in }\end{array}$} & \multirow{2}{*}{$\begin{array}{l}\text { Total } \\
\text { c.r.u. }\end{array}$} \\
\cline { 2 - 4 } & \begin{tabular}{llll} 
a-r \\
\cline { 2 - 3 }
\end{tabular} & Particulates & & \\
\hline $\mathrm{As}$ & 2 & 2 & 2 & 6 \\
$\mathrm{Cu}$ & 1 & 1 & 2 & 4 \\
$\mathrm{~Pb}$ & 2 & 2 & 2 & 6 \\
$\mathrm{SO}_{4}$ & 2 & 2 & 2 & 6 \\
$\mathrm{Zn}$ & 1 & 1 & 2 & 4 \\
Minor & 3 & 3 & 2 & 8 \\
$\quad \begin{array}{l}\text { and trace } \\
\text { elements }\end{array}$ & & & & \\
\hline
\end{tabular}

smaller, such as that for $\mathrm{As}_{2} \mathrm{O}_{3}$ in the B smelter particulates, which would be $0.6 \%$, and the calculated average wt. $\%$ of $\mathrm{As}_{2} \mathrm{O}_{3}$ would lie between $8.1 \%$ and $9.3 \%$.

\section{Appendix 2}

Table 11 below is a worked example of the derivation of the quantitative speciation of the $\mathrm{C}$ smelter stack particulates. Using bulk chemical analysis (space considerations allowing only for this example), we determined the percentages and concentrations of analytes in the a-r particulates, the leachate and the leach residue. We then used a step-wise procedure to apportion, on a molar basis, the analytes to the chemical species and compounds detected by XRD, SEM/EPMA, BSE, EDS and WDS characterisation. The calculated compositions are based on the components' values recovered from the leachate and leach residue.

Table 9 presents the results of leaching $20.00131 \mathrm{~g}$ of $\mathrm{C}$ smelter stack particulates in $1,800 \mathrm{~mL}$ of OECD 203, and then diluting the filtrate with d.i. water to $2,000 \mathrm{~mL}$.

We have normalised the data to moles of component per $100 \mathrm{~g}$ of a-r smelter particulates. For a given component, we have calculated its percentage in the a-r particulates from its analyses in the leachate and the residue, and its mass balance as a percentage of the quotient of the molar quantity recovered in the leachate plus that in the residue divided by the molar quantity in the a-r particulates. Table 3 provides data on the weight percentages of the analytes in the a-r $\mathrm{C}$ smelter particulates, and the percentages of the leached and residue analytes, as well as the mass balances.

In this example, $0.0393 \mathrm{~mol}$ of $\mathrm{Pb}$ reported to the residue, which also contained $0.0366 \mathrm{~mol}$ of $\mathrm{SO}_{4}$. From the XRD pattern of Fig. 2, we assign all $0.0366 \mathrm{~mol}$ of $\mathrm{SO}_{4}$ in the residue to anglesite, $\mathrm{PbSO}_{4}$, leaving $0.0028 \mathrm{~mol}$ of $\mathrm{Pb}$, which we assign to $\mathrm{PbO}$, likely associated with agglomerates, in the residue. Only $7.2 \times 10^{-6} \mathrm{~mol}$ of $\mathrm{Pb}$ leached. Thus, we calculate that the a-r sample contained $11.09 \% \mathrm{PbSO}_{4}$ and $0.62 \% \mathrm{PbO}$. With $8.28 \% \mathrm{~Pb}$ in the a-r particulates, or $0.0400 \mathrm{~mol} \mathrm{~Pb} / 100 \mathrm{~g}$ of sample, the $\mathrm{Pb}$ mass balance is $100(0.0393+7.2 \times$ $\left.10^{-6}\right) / 0.0400=98 \%$. 
Table 11 Worked example of derivation of quantitative characterisation of $\mathrm{C}$ smelter stack particulates $20.00131 \mathrm{~g} \mathrm{C}$ Smelter a-r (as-received) sample leached in 1,800 mL OECD 203, then diluted to 2,000 $\mathrm{mL}$

\begin{tabular}{|c|c|c|c|c|c|c|c|c|}
\hline Component & $\begin{array}{l}\text { Average } \\
\text { wt } \%\end{array}$ & $\begin{array}{l}\text { Moles in a-r } \\
\text { sample/100 g } \\
\text { sample }\end{array}$ & $\begin{array}{l}\text { Moles } \\
\text { leached } / 100 \mathrm{~g} \\
\text { sample }\end{array}$ & $\begin{array}{l}\text { Moles in } \\
\text { residue } / 100 \mathrm{~g} \\
\text { sample }\end{array}$ & $\begin{array}{l}\text { Moles in } \\
\text { (residue plus } \\
\text { leachate)/ } \\
100 \mathrm{~g} \text { sample }\end{array}$ & $\begin{array}{l}\text { Mass } \\
\text { balance, } \\
\%\end{array}$ & \multicolumn{2}{|c|}{$\begin{array}{l}\text { Calculated } \\
\text { composition, \%, based on } \\
\text { recovered values }\end{array}$} \\
\hline $\mathrm{Pb}$ & 8.28 & 0.0400 & 7.2E-06 & 0.0393 & 0.0393 & 98 & & \\
\hline $\mathrm{SO}_{4}$ & 22.36 & 0.2328 & 0.2006 & 0.0366 & 0.2371 & 102 & as $\mathrm{PbSO}_{4}$ & 11.09 \\
\hline bal $\mathrm{Pb}$ & & & & 0.0028 & & & as $\mathrm{PbO}$ & 0.62 \\
\hline bal $\mathrm{SO}_{4}$ & & 0.1928 & 0.2006 & 0.0000 & 0.1978 & & & \\
\hline $\mathrm{Cu}$ & 5.68 & 0.0894 & 0.0115 & & & & as $\mathrm{CuSO}_{4}$ & 1.83 \\
\hline bal $\mathrm{SO}_{4}$ & & & 0.1891 & & & & & \\
\hline $\mathrm{Zn}$ & 17.58 & 0.2689 & 0.2177 & & & & & \\
\hline bal $\mathrm{SO}_{4}$ & & & 0.1891 & & & & as $\mathrm{ZnSO}_{4} \cdot \mathrm{H}_{2} \mathrm{O}$ & 33.93 \\
\hline bal Zn & & & 0.0286 & & & & & \\
\hline $\mathrm{bal} \mathrm{SO}_{4}$ & & & 0.0000 & & & & & \\
\hline $\mathrm{Zn}$ & & & 0.0286 & & & & as $\mathrm{ZnO}$ & 2.32 \\
\hline As & & & & 0.1361 & & & & \\
\hline $\mathrm{Zn}$ & & & & 0.1004 & 0.3181 & 118 & & \\
\hline $\mathrm{Cu}$ & & & & 0.0798 & 0.0912 & 102 & & \\
\hline $\begin{array}{l}\text { Assign } \mathrm{Cu} \\
\text { to undissolved } \\
\left(\mathrm{Cu}_{0.839} \mathrm{Zn}_{0.161}\right) \\
\left(\mathrm{AsO}_{3} \mathrm{OH}\right)\end{array}$ & & & & 0.0951 & & & $\begin{array}{c}\left(\mathrm{Cu}_{0.839} \mathrm{Zn}_{0.161}\right) \\
\left(\mathrm{AsO}_{3} \mathrm{OH}\right)\end{array}$ & 19.37 \\
\hline $\begin{array}{l}\text { Balance of } \\
\text { As as } \mathrm{As}_{2}\end{array}$ & & & & 0.0205 & & & $\begin{array}{l}\text { assigned to } \\
\mathrm{Zn}_{3}\left(\mathrm{AsO}_{4}\right)_{2}\end{array}$ & 9.71 \\
\hline $\begin{array}{l}\mathrm{Zn} \text { in } \\
\left(\mathrm{Cu}_{0.839} \mathrm{Zn}_{0.161}\right) \\
\left(\mathrm{AsO}_{3} \mathrm{OH}\right)\end{array}$ & & & & 0.0153 & & & & \\
\hline $\begin{array}{l}\mathrm{Zn} \text { in } \mathrm{Zn}_{3} \\
\quad\left(\mathrm{AsO}_{4}\right)_{2}\end{array}$ & & & & 0.0615 & & & & \\
\hline & & & & 0.0768 & & & & \\
\hline Balance of $\mathrm{Zn}$ & & & & 0.0236 & & & assigned to $\mathrm{ZnO}$ & 1.92 \\
\hline As & 17.66 & 0.2357 & 0.1121 & & & & as $\mathrm{As}_{2} \mathrm{O}_{3}$ & 11.09 \\
\hline As total & & & & & 0.2482 & 105 & & \\
\hline $\mathrm{K}$ & 2.25 & 0.058 & 0.0576 & 0.0027 & 0.0603 & 105 & as $\mathrm{K}_{2} \mathrm{O}$ & 2.84 \\
\hline $\mathrm{Na}$ & 0.554 & 0.024 & 0.0242 & 0.0007 & 0.0249 & 103 & as $\mathrm{Na}_{2} \mathrm{O}$ & 0.77 \\
\hline $\mathrm{Cd}$ & 0.603 & 0.0054 & 0.0028 & 0.0025 & 0.0053 & 99 & as $\mathrm{CdO}$ & 0.68 \\
\hline $\mathrm{Fe}$ & 0.829 & 0.0148 & 4.2E-06 & 0.0138 & 0.0138 & 93 & as $\mathrm{Fe}_{2} \mathrm{O}_{3}$ & 1.10 \\
\hline $\mathrm{Si}$ & 0.196 & 0.0070 & & & & & as $\mathrm{SiO}_{2}$ & 0.42 \\
\hline $\mathrm{Sb}$ & 0.208 & 0.0017 & $4.9 \mathrm{E}-05$ & 0.0019 & 0.0020 & 116 & as $\mathrm{Sb}_{2} \mathrm{O}_{5}$ & 0.32 \\
\hline $\mathrm{Ca}$ & 0.131 & 0.0033 & -0.0008 & 0.0014 & 0.0014 & 42 & as $\mathrm{CaO}$ & 0.18 \\
\hline $\mathrm{Al}$ & 0.077 & 0.0029 & 2.2E-05 & $2.0 \mathrm{E}-03$ & 0.0020 & 69 & as $\mathrm{Al}_{2} \mathrm{O}_{3}$ & 0.10 \\
\hline $\mathrm{C}$ & 0.025 & 0.0021 & & & & & $\mathrm{C}$ & 0.025 \\
\hline $\mathrm{Mg}$ & 0.013 & 0.0005 & -0.0004 & 0.0002 & 0.0002 & 41 & as $\mathrm{MgO}$ & 0.022 \\
\hline $\mathrm{Ag}$ & 0.0063 & $5.8 \mathrm{E}-05$ & $1.2 \mathrm{E}-07$ & $6.8 \mathrm{E}-05$ & $6.8 \mathrm{E}-05$ & 117 & $\mathrm{Ag}$ & 0.007 \\
\hline $\mathrm{Se}$ & 0.0085 & 0.00011 & $4.6 \mathrm{E}-06$ & $2.1 \mathrm{E}-05$ & $2.6 \mathrm{E}-05$ & 24 & as $\mathrm{SeO}_{2}$ & 0.003 \\
\hline $\mathrm{Cr}$ & 0.0006 & $1.15 \mathrm{E}-05$ & $6.7 \mathrm{E}-08$ & 7.1E-06 & 7.2E-06 & 62 & as $\mathrm{Cr}_{2} \mathrm{O}_{3}$ & $5 \mathrm{E}-04$ \\
\hline $\mathrm{Ni}$ & 0.0004 & $6.8 \mathrm{E}-06$ & $2.9 \mathrm{E}-06$ & $2.2 \mathrm{E}-06$ & $5.2 \mathrm{E}-06$ & 76 & as $\mathrm{NiO}$ & $\begin{array}{l}4 \mathrm{E}-04 \\
98.36\end{array}$ \\
\hline
\end{tabular}

Moreover, in addition to the $0.0366 \mathrm{~mol}^{\text {of } \mathrm{SO}_{4}}$ in the residue, $0.2006 \mathrm{~mol}$ of $\mathrm{SO}_{4}$ reported to the leachate, for a total of $0.2371 \mathrm{~mol}$, which compares favourably with the $0.2328 \mathrm{~mol}$ in the a-r stack particulates and yields a mass balance for $\mathrm{SO}_{4}$ of $102 \%$. 
The a-r stack particulates also contained 5.68\% $\mathrm{Cu}$ or $0.0894 \mathrm{~mol}$. Of the $0.0115 \mathrm{~mol}$ of $\mathrm{Cu}$ in the filtrate, we assume that all was leached from the ar stack particulates as the sulphate, yielding 1.83\% $\mathrm{CuSO}_{4}$ in the initial sample and leaving $0.1891 \mathrm{~mol}$ of unassigned dissolved $\mathrm{SO}_{4}$.

We apportion the remaining $0.1891 \mathrm{~mol}$ of dissolved $\mathrm{SO}_{4}$ to gunnigite, $\mathrm{ZnSO}_{4} \cdot \mathrm{H}_{2} \mathrm{O}$, as detected in the XRD pattern of Fig. 7, yielding $33.93 \%$. This attribution has accounted for all the remaining dissolved $\mathrm{SO}_{4}$, and leaves $0.0286 \mathrm{~mol}$ of dissolved $\mathrm{Zn}$ which we assign to $\mathrm{ZnO}, 2.32 \%$.

With about $58 \%, 37 \%$ and $89 \%$ of the As, $\mathrm{Zn}$ and $\mathrm{Cu}$ unleached, respectively, the residue contained $19.33 \% \quad(0.1361 \mathrm{~mol})$ As, $12.45 \%$ (0.1004 mol) Zn and 9.61\% (0.0798 mol) Cu.

From WDS analysis \#5 of Table 4 and Fig. 9c, we assign the $0.0798 \mathrm{~mol}$ of undissolved $\mathrm{Cu}$ to $\left(\mathrm{Cu}_{0.84} \mathrm{Zn}_{0.16}\right)\left(\mathrm{AsO}_{3} \mathrm{OH}\right)$, which yields $0.0951 \mathrm{~mol}$ of this $\mathrm{Cu}-\mathrm{Zn}$ arsenate, or $19.37 \%$. Since the $\left(\mathrm{Cu}_{0.84} \mathrm{Zn}_{0.16}\right)\left(\mathrm{AsO}_{3} \mathrm{OH}\right)$ also contains $0.0951 \mathrm{~mol}$ of As, we are left with $0.0205 \mathrm{~mol}$ of $\mathrm{As}_{2}$, all of which, from Fig. 9e indicating that $\mathrm{Zn}$ was associated with an arsenate, we assign to the insoluble $\mathrm{Zn}_{3}\left(\mathrm{AsO}_{4}\right)_{2}$ [A-1] at $9.71 \%$. In the process, we have sequestered $0.0615 \mathrm{~mol}$ of $\mathrm{Zn}$, leaving $0.0236 \mathrm{~mol}$ of $\mathrm{Zn}$, which we assign in turn to $\mathrm{ZnO}$.

Between the solution and residue, the $\mathrm{Zn}$ mass balance is $100(0.2177+3(0.0335)) / 0.2689=$ $118 \%$, somewhat greater than desirable, but nonetheless acceptable. The $\mathrm{Cu}$ mass balance is $100(0.0115+0.0798) / 0.0894=102 \%$, which is quite good.

Arsenolite is readily identified in Fig. 7. Moreover, since about $48 \%$ of the As in the a-r stack sample dissolved, we apportion this amount to the relatively soluble $\mathrm{As}_{2} \mathrm{O}_{3}$ [B-1], 11.09\%, which with the $10.20 \%$ by weight of the a-r particulates as undissolved As associated with the arsenates, yields the mass balance for As of $100(0.1121+0.1361) / 0.2357=105 \%$, again quite good.

While they may not exist as discrete compounds, we assume that $\mathrm{K}$ and $\mathrm{Na}$ exist as oxides in some form and so have calculated the percentages of $\mathrm{K}_{2} \mathrm{O}$ and $\mathrm{Na}_{2} \mathrm{O}$ to be 2.84 and 0.77, respectively, with corresponding mass balances of 105 and $103 \%$. The $0.42 \% \mathrm{SiO}_{2}$ is obtained from the percentage of $\mathrm{Si}$ in the a-r particulates.
We also assume that $\mathrm{Cd}, \mathrm{Fe}, \mathrm{Sb}, \mathrm{Se}, \mathrm{Ni}$ and $\mathrm{Cr}$ all exist as their respective oxides, so that their calculated weights in the a-r particulates vary between $4 \times 10^{-4}$ and $1.1 \%$. Because the differences between the measured concentrations of $\mathrm{Ca}$ and $\mathrm{Mg}$ in the OECD 203 leachate and those in the OECD medium were negative, we have simply converted the percentages of $\mathrm{Ca}$ and $\mathrm{Mg}$ in the a-r particulates to $0.18 \% \mathrm{CaO}$ and $0.022 \% \mathrm{MgO}$. Moreover, we calculate $\mathrm{Al}_{2} \mathrm{O}_{3}$ to be $0.10 \%$ and Ag to be $0.007 \%$. As might be anticipated with such low percentages, the mass balances vary between quite good as the $99 \%$ for $\mathrm{Cd}$ as $\mathrm{CdO}$, the low of $24 \%$ for $\mathrm{Se}$ as $\mathrm{SeO}_{2}$, and the high of $116 \%$ for $\mathrm{Sb}$ as $\mathrm{Sb}_{2} \mathrm{O}_{5}$.

The total mass balance for the $\mathrm{C}$ smelter stack particulates leached in the OECD 203 medium was $98.34 \%$, which is close to the objective of achieving a $100 \%$ mass balance.

Other than the discrete compounds gunningite, $\mathrm{ZnSO}_{4} \cdot \mathrm{H}_{2} \mathrm{O}$; anglesite, $\mathrm{PbSO}_{4}$; and arsenolite, $\mathrm{As}_{2} \mathrm{O}_{3}$, the compounds for which we have presented calculated percentages in Table 11 were not detected by XRD. However, apportioning of the insoluble $\mathrm{Cu}$ and $\mathrm{Zn}$ to calculated amounts of $\mathrm{Cu}-\mathrm{Zn}$ arsenate and $\mathrm{Zn}$ arsenate is consistent with the SEM/EPMA detection of $\mathrm{Cu}$ and $\mathrm{Zn}$ arsenates in the pristine smelter stack samples, and also accounts for the $\mathrm{Cu}$ and $\mathrm{Zn}$ in the leach residue. The compounds for which we have assigned quantitative speciation may exist in the amorphous and agglomerated material detected by XRD and SEM/EPMA characterisation, respectively.

We have followed the above general approach in developing the quantitative speciation of the ar C smelter stack particulates from the d.i. water and RICH-95 leaching, as well as the A and B particulates.

\section{Appendix 2 Reference}

Godfrey, S.M., McAuliffe, C.A., Mackie, A.G. \& Pritchard, R.G. (1998). Coordination chemistry and solution chemistry. In N.C. Norman (ed.), Chemistry of Arsenic, Antimony and Bismuth (pp 159-205). London: Blackie. 


\section{References}

Barcan, V. (2002). Nature and origin of multicomponent aerial emissions of the copper-nickel smelter complex. Environment International, 28, 451-456.

Beavington, F., Cawse, P. A., \& Wakenshaw, A. (2004). Comparative studies of atmospheric trace elements: Improvements in air quality near a copper smelter. Science of the Total Environment, 332, 39-49.

Biswas, A. K., \& Davenport, W. G. (1994). Extractive metallurgy of copper (p. 305). New York: Elsevier.

Canada Gazette (2006). Vol. 140, no. 17, April 29, 2006. http:/canadagazette.gc.ca/partI/2006/20060429/html/ notice-e.html. Accessed July 24, 2008.

Dana, E. S., \& Ford, W. E. (1958). A textbook of mineralogy (p. 535). New York: Wiley.

Doyle, P. J., Gutzman, D. W., Sheppard, M. I., Sheppard, S. C., Bird, G. A., \& Hrebenyck, D. (2003). An ecological risk assessment of air emission of trace metals from copper and zinc production facilities. Human and Ecological Risk Assessment, 9(2), 607-636.

Environment Canada. (2006). http://www.ec.gc.ca/default. asp?lang $=$ En $\& n=714$ D 9 AAE $-1 \&$ news $=12$ D55D4187CA-4AB9-89AB-9D3D8520AA46. Accessed July 24, 2008.

Ettler, V., Johan, Z., Baronnet, A., Jankovský, F., Gilles, C., Mihaljeè, M., et al. (2005). Mineralogy of airpollution-control residues from a secondary lead smelter: Environmental implications. Environmental Science \& Technology, 39(23), 9309-9316.

Ettler, V., Šebek, O., Grygar, T., Klementová, M., Bezdièka, P., \& Slaviková, H. (2008). Controls on metal leaching from secondary pb smelter airpollution-control residues. Environmental Science \& Technology, 42(21), 7878-7884.

Gieré, R., Blackford, M., \& Smith, K. (2006). TEM study of PM2.5 emitted from coal and tire combustion in a thermal power station. Environmental Science \& Technology, 40, 6235-6240.

Godfrey, S. M., McAuliffe, C. A., Mackie, A. G., \& Pritchard, R. G. (1998). In N. C. Norman (Ed.), Chemistry of arsenic, antimony and bismuth (pp. 191-197). London: Blackie.

Karczewska, A. (1996). Metal species distribution in topand sub-soil in an area affected by copper smelter emissions. Applied Geochemistry, 11, 35-42.
OECD (1992). OECD Guideline for Testing Chemicals. Fish, Acute Toxicity Test. http://www.oecd.org/ dataoecd/17/20/1948241.pdf. Accessed, 2001.

OECD (2001). Harmonised Integrated Classification System for Human Health and Environmental Hazards of Chemical Substances and Mixtures. OECD Series on Testing and Assessment, Number 33. OECD Environment Directorate, Environment, Health and Safety Division, 2 rue André-Pascal, 75775 Paris Cedex 16, France. http://www.olis.oecd.org/olis/2001doc. nsf/LinkTo/NT00004D4E/\$FILE/JT00111570.PDF. Accessed Feb. 14, 2007.

Samuelsson, C., \& Björkman, B. (1998). Dust-forming mechanisms in the gas cleaning system after the copper converting process. Scandinavian Journal of Metallurgy, 27(2), 54-63.

Samuelsson, C., \& Carlsson, G. (2001). Characterization of smelter dusts. CIM Bulletin, 94(1051), 111-115.

Sánchez de la Campa, A. M., de la Rosa, J. D., SanchezRodas, D., Oliveira, V., Alastuey, A., Querol, X., et al. (2008). Arsenic speciation study of PM2.5 in an urban area near a copper smelter. Atmospheric Environment, 42, 6487-6495.

Sánchez-Rodas, D., Sánchez de la Campa, A. M., de la Rosa, J. D., Oliveira, V., Gomez-Ariza, J. L., Querol, X., et al. (2007). Arsenic speciation of atmospheric particulate matter (PM10) in an industrialised urban site in southwestern Spain. Chemosphere, 66, 14851493.

Sobanska, S., Ricq, N., Laboudigue, A., Guillermo, R., Brémard, C., Laureyns, J., et al. (1999). Microchemical investigations of dust emitted by a lead smelter. Environmental Science \& Technology, 33(9), 1334-1339.

UNECE (United Nations Economic Commission for Europe) (1998). Convention on Long-range Transboundary Air Pollution (LRTAP) Protocol on Heavy Metals. http://www.unece.org/env/lrtap/hm_h1.htm. Accessed July 24, 2008.

United Nations (2009). Globally Harmonized System of Classification and Labelling of Chemicals, ST/SG/AC. 10/30/Rev.3. http://www.unece.org/trans/danger/publi/ ghs/ghs_rev03/03files_e.html. Accessed Apr. 21, 2010.

Wong, H. K. T., Banic, C. M., Robert, S., Nejedly, Z., \& Campbell, J. L. (2006). In-stack and in-plume characterisation of particulate metals emitted from a copper smelter. Geochemistry: Exploration, Environment, Analysis, 6, 131-137. 